Historic, Archive Document

Do not assume content reflects current scientific knowledge, policies, or practices. 
, 


\section{LANDEWATER MANAGEMENT BIOLOGY Training School \\ A12, 9
So32}

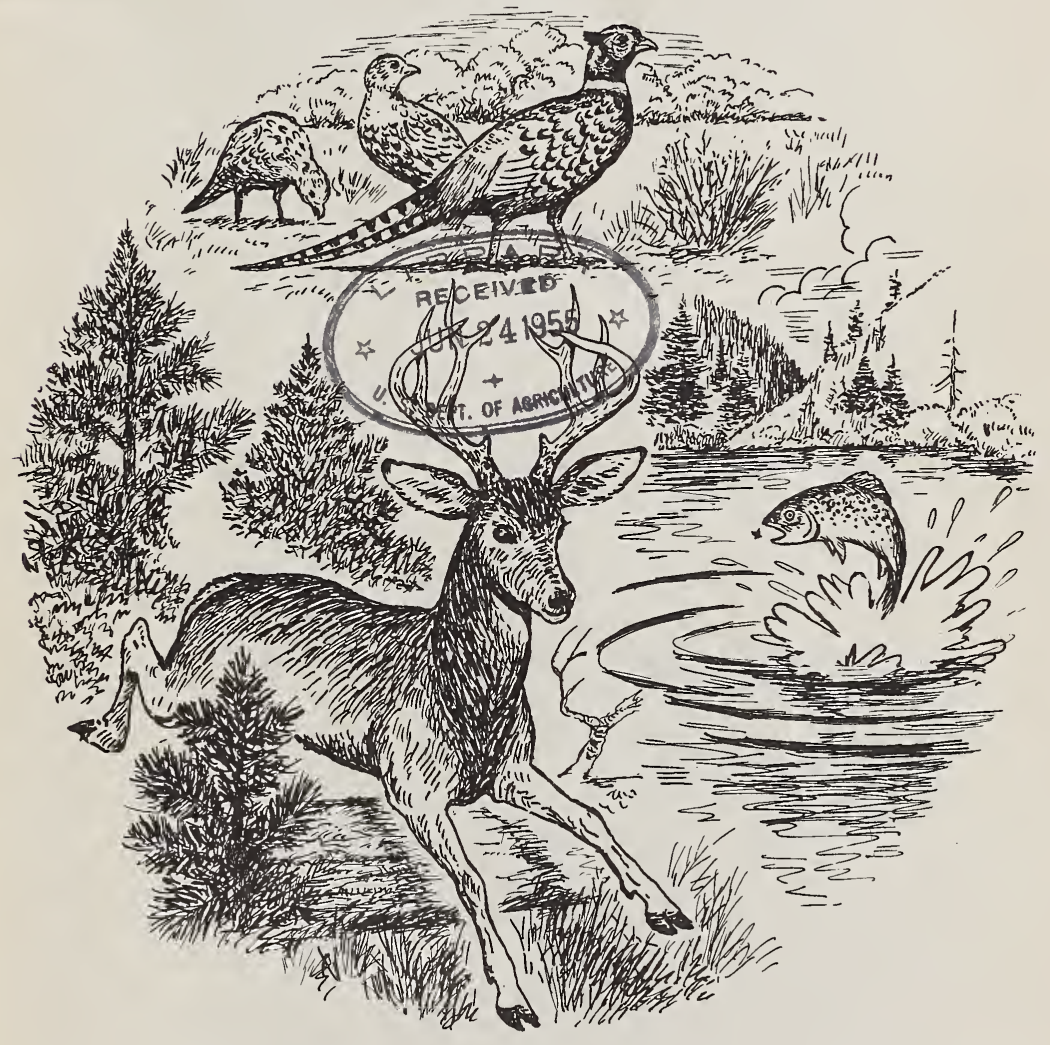

U.S. SOIL CONSERVATION SERVICE and State Department of Fish and Game Cooperating. 


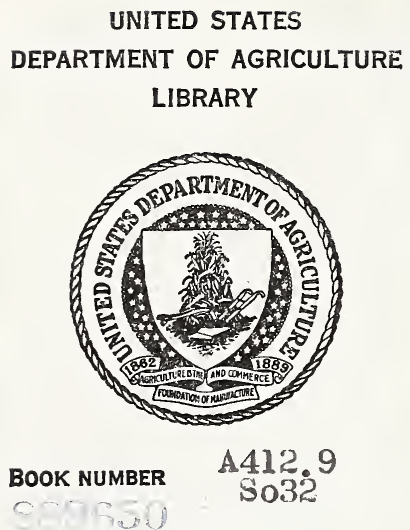


SOIL CONSERVATION SERVICE OBJECTIVES AND POLICY CONCERNING THE BIOLOGICAL PHASES OF SOIL AND IJATER CONSERVATION

The Soil Conservation Service is the agency of the U. S. Department of Agriculture charged with the responsibility for bringing to farmers and ranchers (SCD cooperators) all of the agricultural techniques that are concerned with the management of $l$ and and water for soil and vater conservation. These tecnniques include those designed for the development, management and use of firm and ranch lands and water for the perpetuation, conservation, or production of fish and useful forms of wildlife. This broad responsibility is shown by the following objectives:

\section{SOIL COINSERVATION SERVICE BIOLCGY OBJECTIVES}

1. To apply to land-use problems biological knowledge useful in the prevention of soil erosion and in soil and water conservation, thereby preserving natural resources.

2. To achieve productive land use, particularly on lands not adapted to yields of tilled crops, livestock forage, or wood products.

? To assist in the solution of land-use problems which involve production of usiful wild plants and animals op croplands, grazing lands, and woodlands.

4. To assist with the prevention and control of biological damage arising out of measures established for soil and water conservation and related landuse practices.

\section{SOII CONSERVATION SERVICE POLICY}

Soil Conservation Service policy governing activities of its personnel in the planning and application phases of land and water management biology is stated as follows:

The Soil Conservation Service will provide technical help to farmers and ranchers upon request, in the design, direction of construction or establishment and management and maintenance of the land and water management biology treatments listed below:

I. Construction and management of privately-owmed ponds for fish production.

IJ. Development and management of wet lands or marshes for waterfowI and/or furbearers. 
III. Development and management of all lands for the production of game and other useful forms of wildlife.

(a) The lands wich should alvays be reconmended for vildlife or recreational use because of land capability (VIII) include such as:

(1) Odd areas

(2) Stream and river banks, potentially erodible by stream cutting

(3) Undrainable wetlands or marshes

(4) Severely eroded areas

(5) Spoilbanks

(b) Lands which are usually recommended for wildlife use:

(1) Woodland borders

(2) Pond margins

(3) Land used for windbreaks, woodlots, etc., with possible border plantings for wildlife

(4) Fence lines

(5) Field borders

(6) Roadsides and lanes

(c) Lands of any land capability class on which the landowner wishes to produce wildlife as a regular land use

The kinds of assistance to be provided to the farmer or ranabergenerally include the following:

1. Farm or ranch ponds

(a) Location of site

(b) Determination of suitability of soils for holding water and building earth-fill dam

(c) Determination of adequacy of water supply

(d) Design of structures

(e) Technical direction of construction

(f) Determination of species of fish adapted for stocking

(g) Determination of stocking rates

(h) Determination of correct techniques and procedures of water and fish management

2. Wetlands and marshes

(a) Location of sites adapted for development

(b) Design of structures involved

(c) Technical direction of development

(d) Determination of techniques and procedures necessary for the development and management of the land and the waterforl or furbearers 
3. Lands used for game and other useful wildlife production.

(a) Location of sites adapted for development or treatment

(b) Design of structures or woody and herbaceous plantings involved

(c) Technical direction of development or plant establishment

(d) Determination of techniques and procedures necessary for the development and management of the land for wildlife production.

In working with landowners on soil and water conservation planning and application, Soil Conservation Service technicians should take advantage of the opportunity to point out the benefits derived by farm wildlife from all conservation treatments. Cf particular imortance to wildlife are such soil and water conservation practices as:

Strip cropping

Winter cover crops

Streambank and pond margin plantings

Windbreak plantings

Ditch and spoilbank seedings
Water developments and ponds

Range management practices

Woodland management practices

Sodded waterways

Exclusion of grazing from

Class VIII lands

Service technicians should also point out the benefits derived by the landowner from having useful kinds of wildlife on his lands. Such wildlife includes:

Game birds and animals

Songbirds

Predators of destructive rodents

Insect-eating birds

Fish

Weed seed-eating birds

Waterfow I

AII land and water management biology recommendations made to farmers or ranchers shall be consistent with good land use and the soil and water conservation program for the lands involved.

Soil Conservation Service technical recomnendations for the use and management of land and water for the production of fish and wildife shall be in accordance with policies of the state fish and game agency and the U. S. Fish and Wildlife Service.

Soil Conservation Service technicians should encourage soil conservation district supervisors to solicit the assistance of the state fish and gam $e$ agency in the district's land and water managenent biology program. 
MEMORANDUI OF UNDERSTANDING

between the

SOIL CONSERVATION DISTRICT

and the

STATE FISH AND GAME CONMISSION

\section{Statement of Purpose}

1 The

Soil Conservation District of

is a govermental

subdivision of the State, organized under the Soil Conservation Districts Law of , for the purpose of excercising public powers in connection with the conservation of soil and soil resources within the District, and is authorized to accept assistance from any agency for this purpose.

The

Soil Conservation District desires the assistance of the the development of fish game and other useful wildlife resources through the District's land and water management program.

The State Fish and Game Commission is the State agency established by law to preserve, protect, perpetuate and manage all wildlife of the State, and is authorized to cooperate with and assist soil conservation districts for this purpose.

15 The

State Fish and Game Commission desires to cooperate with and Soil Conservation District with those phases of the life.

In view of these considerations, and since the District and the Commission 20 each desire to establish an enduring bäsis for such cooperation and assist21 ance, they hereby enter into this liemorandum of Understanding.

THE DISTRICT WILL UNDERTAKE TO:

A. Enter into cooperative agreement with all land owners and operators who request technical assistance in the development and management of all or any part of their lands for the production and conservation of fish, game and other useful wildlife.

B. Provide, Insofar as possible, technical assistance to cooperating land owners and operators for the planning and application of development and management measures for the purposes mentioned above. Such measures shall be consistent with the policies and technical programs of the Commission.

Obtain the necessary agreements or easements where the aid to be furnished the cooperating land owners and operators to carry out the above develogment or management measures involves technical assistance, materials, flsh, equipment, or labor to be provided by the Commission. Tho forms of such agreements or easements shall be acceptable to the Commission. 
D. Provide cooperating land owners and operators with limited amounts of tree and shrub planting stock or grass and legume seed for wildlife habitat development or improvement where (1) such planting materials are used for testing the adaptability and utility of new or improved materials, (2) the planting materials are not on the market at reasonable cost, or (3) such planting materials are used for demonstration of standard conservation practices.

E. Provide the Commission on of each year with the anticipated or obligated needs of the following services or materials to be furnished by the Commission during the second succeeding. calendar year:

1. Planting materials -- number of woody plants of each species and number of pounds of grass or legume seed of each species required and the location of the proposed planting sites.

2. Fish - number of fish of each species required and location and size of ponds.

3. Fencing materials -- amount of each item and location and purpose of proposed fence construction.

4. Other materials -- kind and amount of each item and location and purpose of proposed use.

5. Technical assistance -- specific jobs and suggested dates.

F. Furnish the Commission a writien report within thirty days after December 31 st of each year which will include:

1. Summary of accomplishments of the District for the year ending December 31st.

2. Disposition of all materials provided by the Commission for the year ending December 3lst.

G. Schedule at least cne meeting each year of the Board of Directors for the purpose of considering the wildlife conservation and management needs of the District. At such meetings, the assistance of State Fish and Game Department technician's and representatives of local " sportsmen's organizations will be solicited to:

1. Revise the District Work Program to provide for wildlife conservation and management.

2. Prepare the section of the District's Annual Work Plan that will provide for the continuance of an active land management program for the improvement of conditions for fish and wildlife throughout the District. 
THE COIMISSION WILL UNDERTAKE TO:

77 A. Provide, as available, the land owners and operators cooperating with

78 the District with reasonable quantities of supplies and materials

79 required for the development or improvement of wildlife habitat. The providing of such supplies and materials will take place according to schedules and arrangements which will be furnished by the Commission to the District by of each year.

83 B. Make the necessary surveys, investigations or studies to:

84

85

86

87

88

89

90

91

1. Determine wildlife needs insofar as environmental changes that $c a n$ be readily accomplished by practical land management measures.

2. Determine the adequacy of wildlife management practices, appraise their value and check specific results obtained from materials or other assistance supplied by the Commission.

3. Appraise the value to wildlife of land management practices applied for the control of soil and water loss.

C. Assist in the planning and establishment of wildlife measures which require technical skill beyond the experience of individual land owners and operators.

D. Assist the district in its general conservation educational program by working with schools, $4 \mathrm{H}$ clubs, civic organizations, farm groups, sportsmen and other groups and organizations wi thin the District.

E. Encourage cooperation with the District in those contacts made with land owners and operators who have not entered into cooperative agreements with the District.

101 F. Provide the District with copies of wildlife management plans prepared

102

103 for District cooperators for inclusion as a part of the total conservation farm plan in the Farmer-District Agreement.

104 G. Assist the District in demonstrations of land and water management 105 practices designed for wildlife benefit.

$106 \mathrm{H}$. Assist the District in making revisions of the District Work Plan

107

108

109 and Program for the continuance of an active land management program for the improvement of conditions for fish and wildlife throughout the District.

IT IS MUTUALLY UNDERSTOOD THAT:

111 A. The District has sole responsibility for the carrying out of the 112 provisions of the cooperative agreements entered into between land 113 owners and operators and the District. 
114 B. Neither the Commission nor the District is bound by any obligation in this Remorandum which will entail the expenditures of funds in excess of the amounts legally available to them, or for a period in excess of that authorized by law.

118 C. This Memorandum shall be effective when signed by each of the parties and may be terminated by mutual agreement or by either party upon notice given in writing to the others. It may be modified by mutual agreement at any time.

D. Considerable testing, followed by demonstration may be necessary in the development of practices which are found to be sound -- economical, practical and effective -- for application to a large number of farms within the District for the production of fish, game and other useful wildlife as a part of a program of the sound use of land and water. The first wildlife practices to be tested, evaluated and demonstrated will include the following:

1. Management of farm pond and reservoir waters for the production of fish.

131

2. The planting of adapted trees, shrubs, grasses and legumes for wildlife environment improvement in adapted areas. : .

133 3. The planting of perennial grasses on major ditch banks.

134 4. The establishment of farnstead windbreaks utilizing wildlife

135 food and cover woody plants.

136 5. The establishment of woodlots with wildlife food and cover

137 border plantings.

138 6. The use of multiflora rose living fences.

Date :

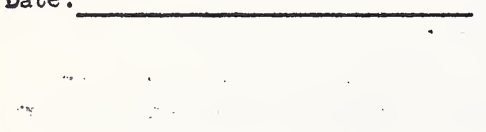
State Fich and Game Comnission Director

Date:

Soil Conservation District Chatrman, Board of Supervisors 
1954 Annual Work Plan I/

(Wildlife Section)

Amador County Soil Conservation District

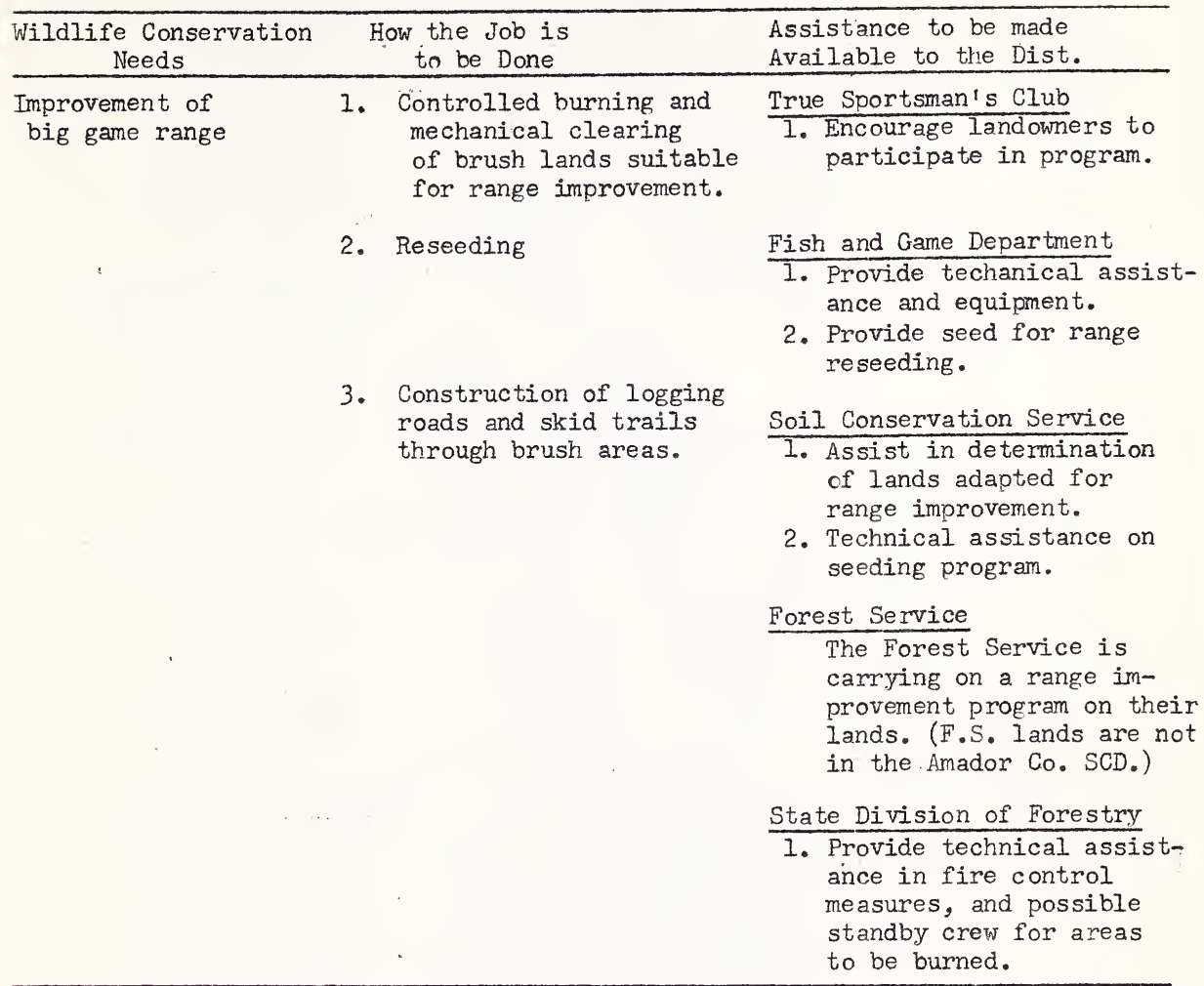

Management of Resident 1. Change in hunting reguDeer Herd lations to permit more effective management of herd.
True Sportsman's Club

1. Sponsor change in hunting regulations to permit more effective management of deer herd.

Fish and Game Department

1. Conduct hearing on modification of hunting regulations.

2. Manage either sex shoot.

3. Determine annual harvest needs.

If Prepared at joint meeting of Amador County Soil Conservation District, True Sportsman's Club, California Department of Fish and Game, and the Coil Conservation Service. 
1954 Annual Work Plan, Cont'd.

\begin{tabular}{ccc}
\hline $\begin{array}{c}\text { Wildlife Conservation } \\
\text { Needs }\end{array}$ & $\begin{array}{c}\text { How the Job is } \\
\text { to be Done }\end{array}$ & $\begin{array}{l}\text { Assistance to be made } \\
\text { Available to the Dist. }\end{array}$ \\
\hline
\end{tabular}

Development of Farm Pond Fisheries
1. Construction and management of farm ponds and reservoirs for fish production.
True Spor tsman's Club

1. Encourage landowners to particioate in program.

2. Sponsor pond construction and management demonstrations.

Fish and Game Department

1. Provide technical assistance in stocking and management for fish production.

2. Provide initial stockwarm water species, consistant with regulations.

Soil Conservation Service

1. Provide engineering assistance in design and construction of ponds and reservoirs.

2. Provide technical assistance in management for fish production.
Quail Habitat

Improvement
1. Strip and spot clearing of brush lands.

2. Brush piling on selected sites (Class VIII lands).

3. Ilaintenance of adequate roosting cover.

4. Placement of "guzzlers"

... at selected sites.

5. Planting of adapted food and cover.

6. Fencing farm ponds.
True Sportsman's Club

1. Encourage landowners to participate in program.

2. Assist in educational work.

3. Assist in posting "Hunting by permission" and "Safety Zone" signs.

Fish and Game Department

1. Provide technical assistance in planning and application.

2. Provide equipment in clearing program.

3. Construct "guzzlers."

4. Provide material assistance in pond fencing.

5. Provide planting materials.

Soil Conservation Service

1. Provide technical assistance in planning and application.

2. Provide woody and herbace ous planting stock for testing and observation. 


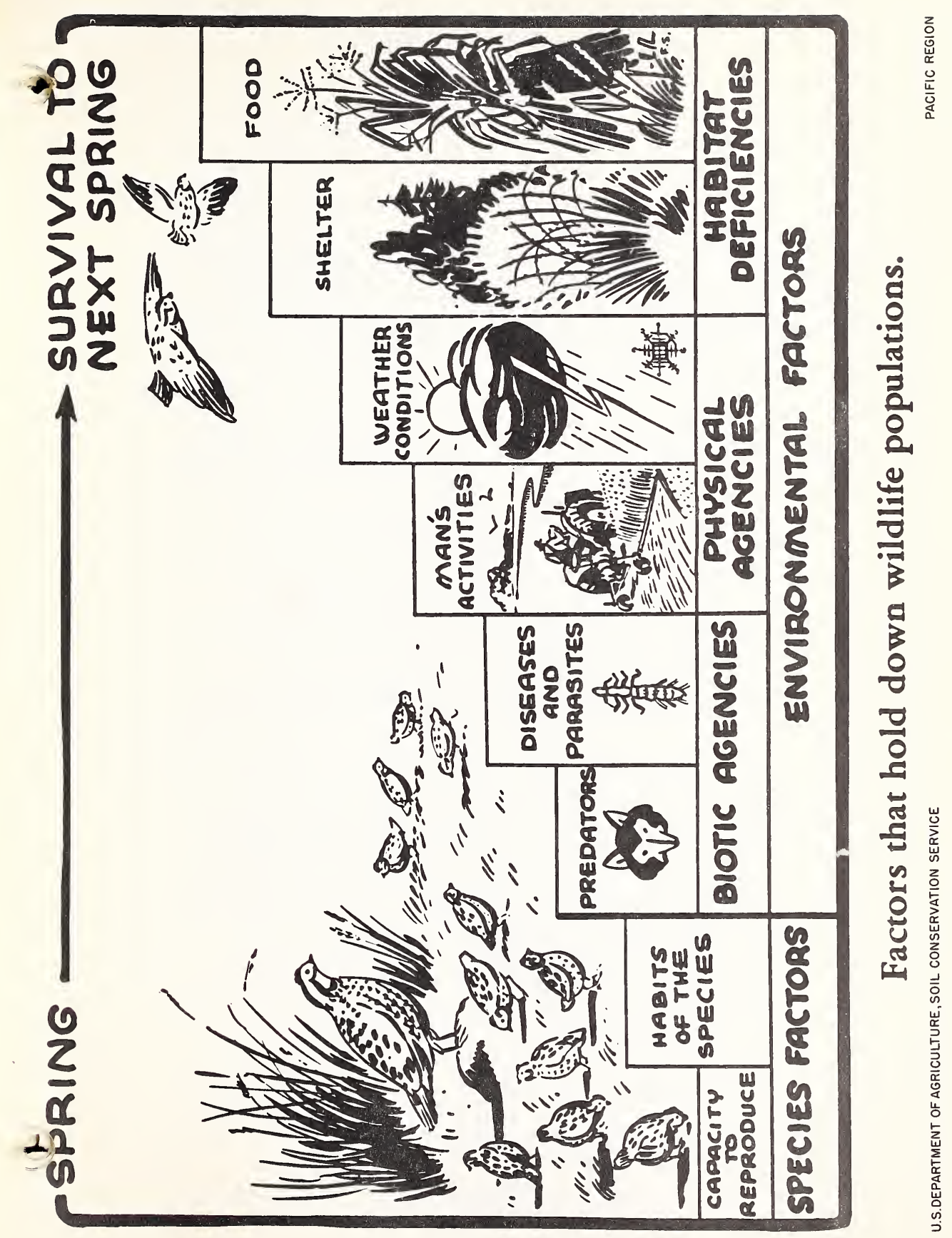


UNITED STATES DEPARTMENT OF AGRICULTURE

SOIL CONSERVATION SERVICE

Pacific Region

PLANTING TREES AND SHRUBS FOR FARM WILDLIFE

\section{Introduction}

Effective windbreak and wildlife plantings must be properly planned, planted and cared for. Adapted trees and shrubs, well cared for and on good sites will begin to be effective in three to five years. Tree plantings should be considered as long-term investments which increase in value as they become older. By increasing crop, yields, cattle gains and wildlife and by improving the living conditions on the farm, the cash value of the farm will increase.

\section{Site selection}

Selection of good planting sites is of primary importance. A good site may be hard to find, but it is better to have a few successful plantings than many failures.

A. Soil depth--A rule of thumb is that if it's too shallow to grow a good crop, it's too shallow for trees.

B. Alkali--There are only a limited number of trees that will grow well under alkali conditions.

C. Drainage--Willows, poplars and redosier dogwood are about the only species that can stand "wet feet."

D. Noxious weeds--All perennial weeds must be killed before the planting is made.

\section{Planting design}

A. Lay out the planting so maximum benefits can be effected.

B. Design the planting for maximum ease and use of equipment with minimum hand maintenance.

C. Plantings should be at least 100' from buildings.

D. Spacing is important--Without proper spacing trees cannot be cultivated; without cultivation the planting will not become established.

Spacing between rows Spacing between plants in the row

$\begin{array}{llll}\text { Irrigation: } & \text { In' } & \text { Small shrubs } & 31 \\ \text { Dryland: } & 12 ' \text { or more } & \text { Tall shrubs or } & \text { small trees }\end{array}$

Deciduous trees \&

Evergreens $18^{\prime}$ or more Tall deciduous trees 121

Evergreens 
E. Plant tall trees in the center rows.

F. Plant evergreens in the leeward rows for protection during their establishment period.

IV. Species selection

A. Select only species well adapted to the planting site.

B. Select trees and shrubs that will be available.

C. Put in orders as early as possible for tree stock to avoid substitution.

V. Planting establishment

Since time, labor, land and money are going into the planting, every effort should be taken to plant the trees correctly.

A. Plant in the spring as soon as the frost is out of the ground and the ground can be disked.

B. Open the bundle of trees as soon as they arrive to prevent heating. Keep the trees in a cool, moist place with the roots covered until ready to plant. If there is a delay in planting, pack the roots in soil.

C. Planting

1. Shovel-mig the hole or make a slit deep enough so that the roots can be spread out. Put the plant about one inch deeper than it was planted in the nursery.

2. Furrow--Open a deep furrow with a moldboard plow and place the trees at the proper spacing and depth in the furrow. The tree roots are then covered, the row completed and the furrow plowed in. Pack the soil in the furrow with the large wheel of the tractor. Check to see that all plants are planted properly.

D. Carry the plants in a bucket of water or mud while planting. This is important with deciduous trees, essential with evergreens. If evergreen roots dry out, there is little chance for their survival. 
VI. Planting maintenance

A. Fence to exclude livestock and chickens. Chickens are especially hard on small evergreens.

B. Keep out fire.

C. Clean cultivate. Under dryland conditions, a planting has little chance for success without cultivation during the establishment period. Cultivate only deep enough and often enough to kill all weeds.

D. Use a non-competitive cover crop such as blue wildrye when cultivation is stopped.

E. Prune deciduous trees where narrow "V" crotches may split from wind damag": Prune Caragana to the ground the first year to thicken it up. Do not prune the evergreens. 


\section{SOIL AND MOISTURE CONSERVATION PRACTICES OF VALUE TO WILDLIFE SHRUB BORDERS ON WOODLOT PLANTINGS}

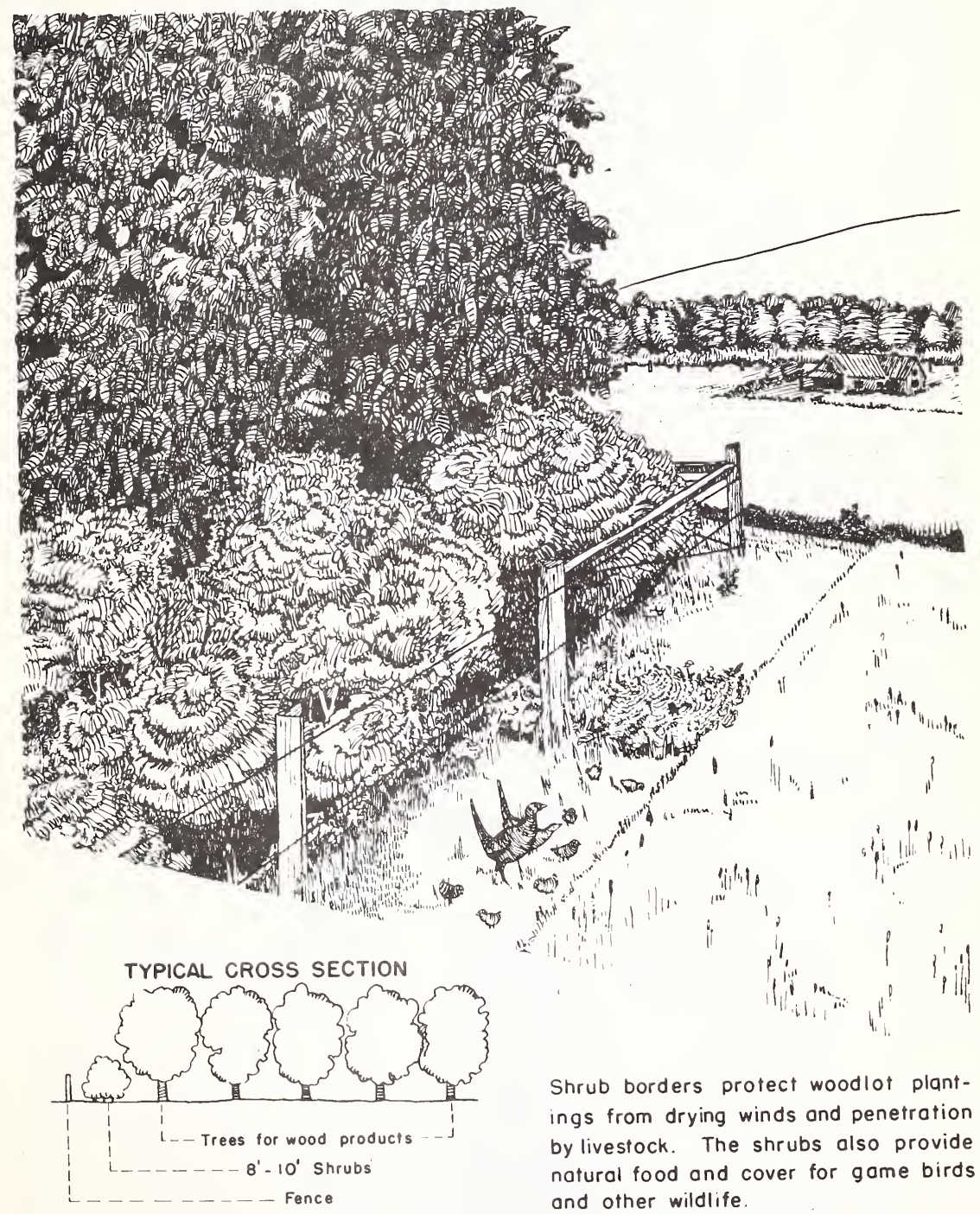




\section{PLANMING A FARMSTEAD WINDBREAK}

\section{A Farmstead Windbreak Means:}

Real protection to both home and livestock against winds and snow. Careful measurements have shown that fuel consumption in the home can be reduced by 20 to 30 percent. Experiment stations have shown that the feedlot livestock will gain. faster and require less feed.

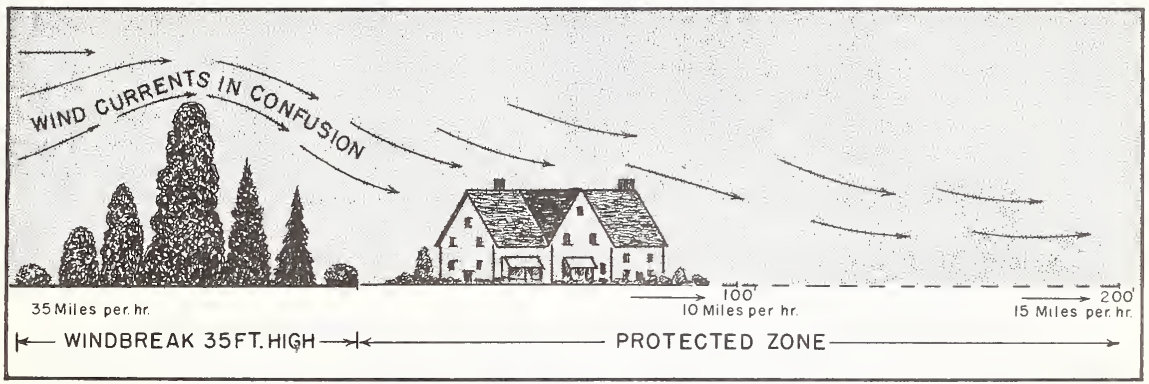

\section{A dryland windbreak must be cultivated for the first few years or the survival and growth will not be satis factory.}

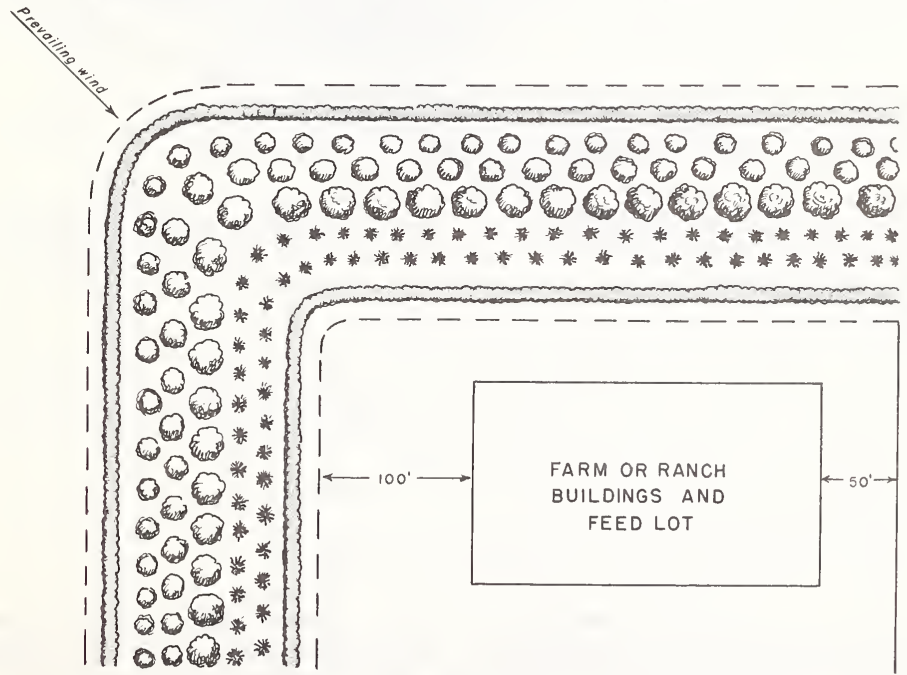

Plan the location of windbreaks, number, length and arrangement or rows for maximum protection from the prevailing wind. 


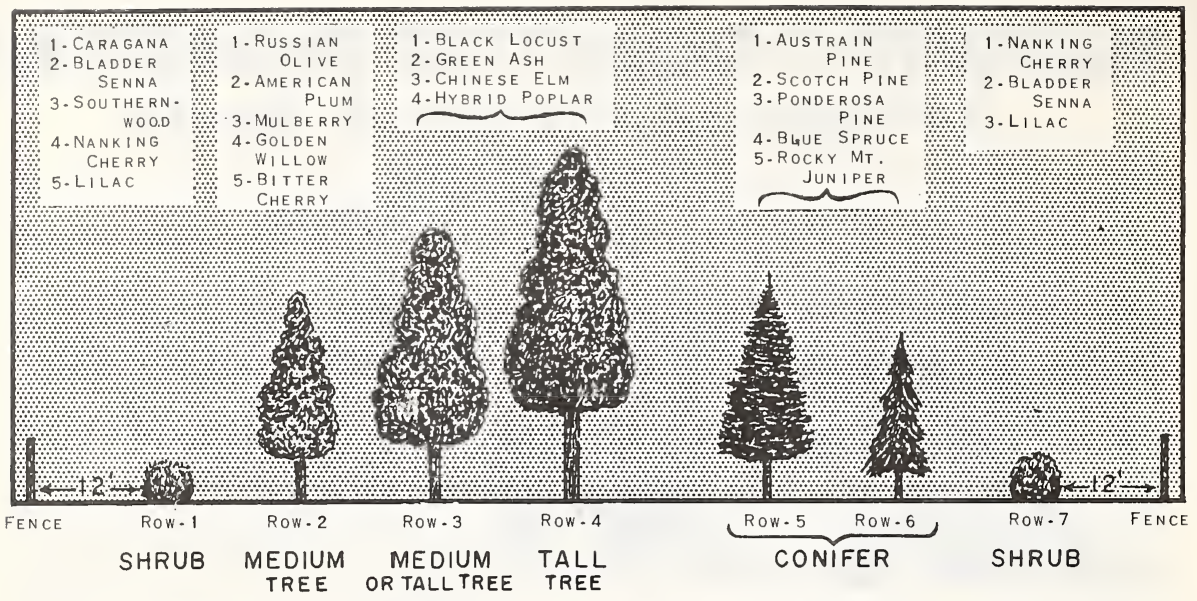

\section{Plant 3 - 5 or 7 row windbreak}

\section{For 3 row wimdlbreak plant rows $1-3-5$ For 5 row windlbreak plant rows 1-2-4-5-}

\section{Planting ReCOMMendations}

1. Plant $100^{\prime}$ from the main buildings or $50^{\prime}-75^{\prime}$ from a feedlot.

2. Plow ground previous to planting, preferably in the fall.

Kill all perennial weeds before planting.

3. Plant as soon as possible in the spring.

4. Protect tree roots from wind and sun during planting. Keep seedlings moist until planted.

5. Space trees $12^{\prime}$ apart in the rows; shrubs $3^{\prime}-4^{\prime}$; evergreens $6^{\prime}$. Space tree rows a minimum of $12^{\prime}$ apart - except evergreen and deciduous rows should be at least $18^{\prime}$ apart. The spacing should be wider in the low rainfall areas or may vary to fit the width of the cultivation equipment.

6. Plant either in a plowed furrow or individual holes dug by hand - do not bend or crowd the roots.

7. Cultivate only often enough and shallow enough to keep the planting free of weeds and grasses.

8. Protect the planting from grazing, poultry, and fire; fence when necessary.

9. Order your trees from the nursery early.

YOUR SOIL CONSERVATION DISTRICT RECOMMENDS THE FOLLOWING KINDS OF TREES AND SHRUBS FOR YOUR WINDBREAK

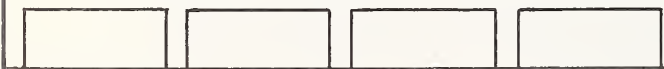


SOIL AND MOISTURE CONSERVATION PRACTICES OF VALUE TO WILDLIFE SHRUB BORDERS ON WINDBREAK PLANTINGS

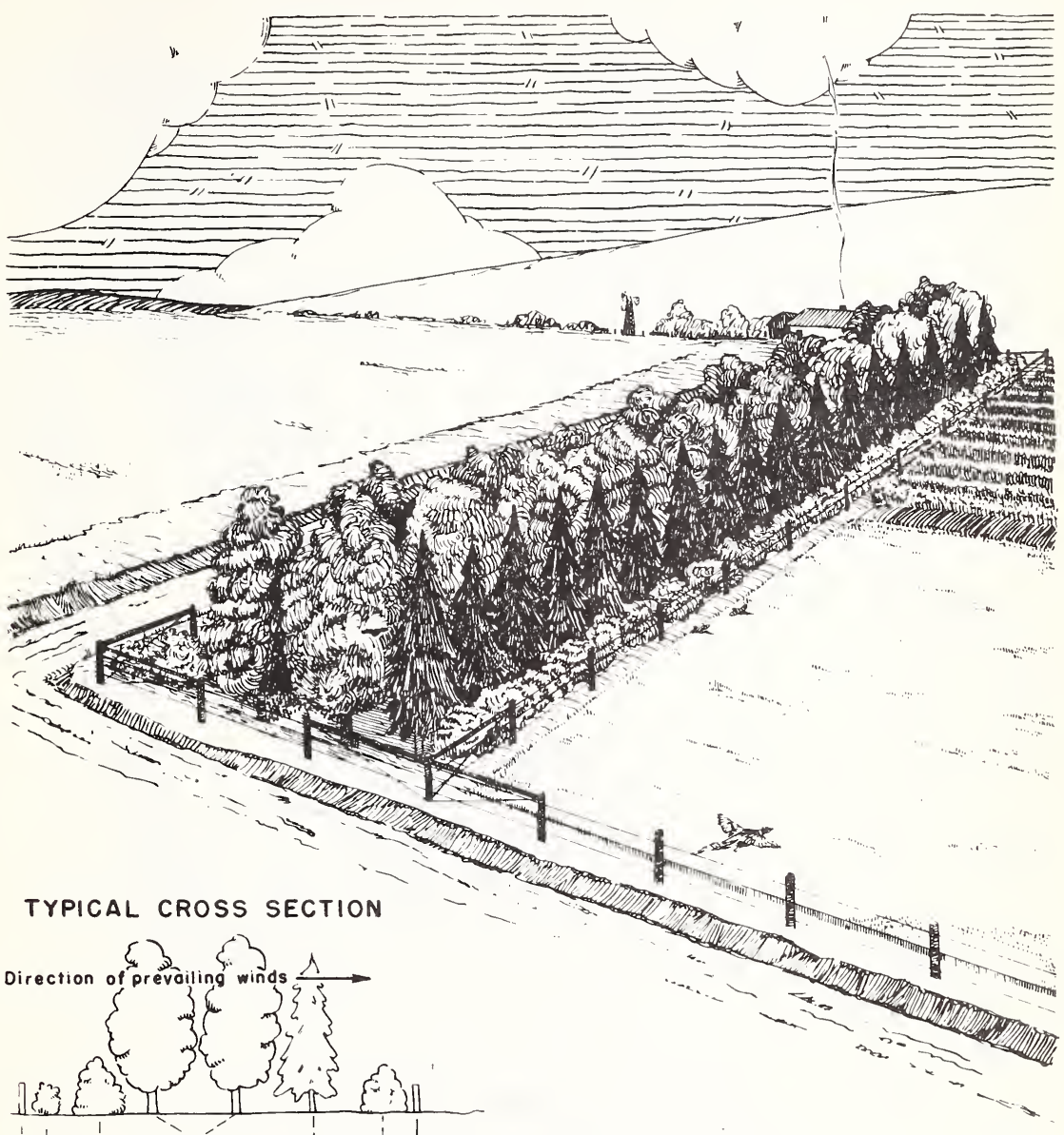

Shrub borders on windbreak plantings are an effective barrier to low ground winds. The shrubs also provide notural food and cover for game birds and other farm wildlife. 
6 
SOIL AND MOISTURE CONSERVATION PRACTICES OF VALUE TO WILDLIFE SNOW FENCE PLANTINGS

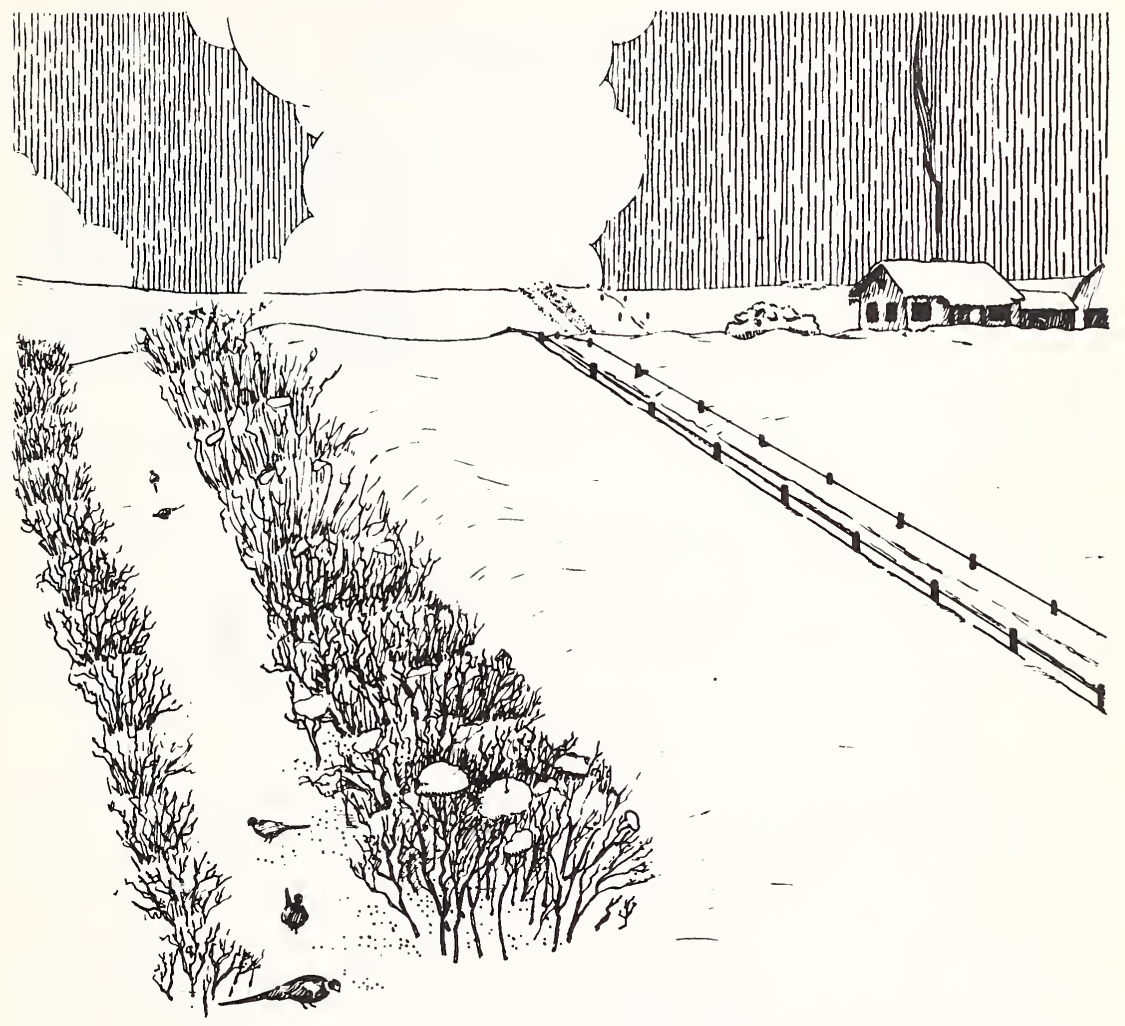

TYPICAL CROSS SECTION

Direction of prevoiling winfer wind.

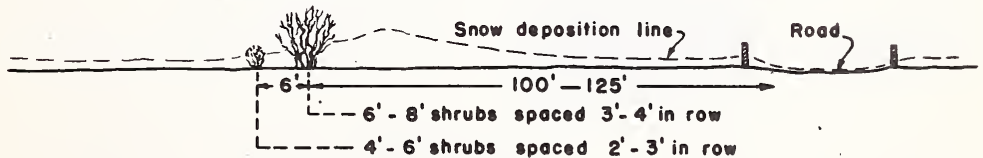

Shrub snow fences keep farm lanes open for winter travel and provide cover for game birds and other form wildlife. 


\section{How to use MULTIFLORA ROSE for living fences and wildlife cover}

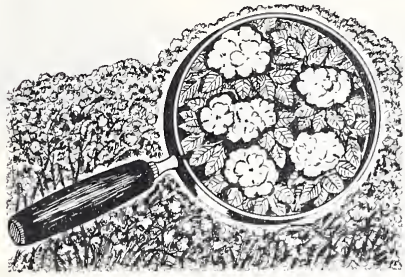

Description of the plant

grow to a height of $8^{\circ}$ to 10 feet and occupy about the same width. and 6 to 8 feet in width.

Multiflora rose does not spread from rootstalks. Drooping side canes, if they touch exposed soil, may take root and grow. There is little spreading from seed. Ordinary care of adjacent ground by mowing, cultivating or grazing will keep the rose from spreading. There is no record of its becoming a nuisance in cultivated fields or well-kept pastures.

\section{Its value}

Multiflora rose plantings are best adapted for use wherever stock-tight living fences are needed for field division or the exclusion of livestock. This type of fence requires no posts, no wire and no maintenance once it is established.

Multiflora rose plantings have been found to be particularly adapted for use as fences along roads or adjacent to woodland and wild lands. This type of planting is not recommended for interior fences unless a strip of ground 10 to 12 feet in width can be devoted to this use. Rose fencing may be found useful for the protection of woodlots or exclusion of livestock from farm ponds, gullied areas, and eroding streambanks.

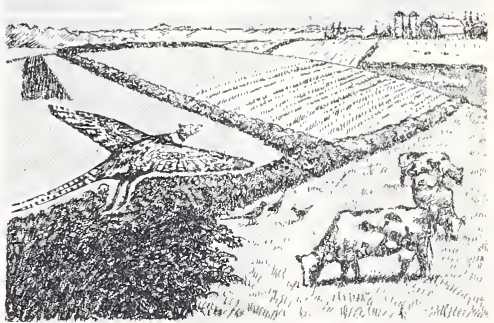

The rose fence provides excellent year around protective cover for many kinds of useful wildlife, including pollinating insects; birds, animals and insects that help destroy crop pests; game birds and animals; and the colorful, musical songbirds that add to the enjoyment of farm iife: Without such protection, many kinds of wildlife will not survive. 


\section{Planting site requirements}

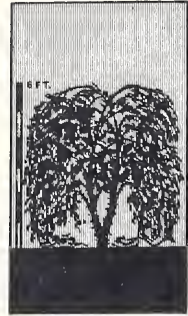

Good Site

Like most plants, multiflora rose grows best on deep, fertile soils. When seedlings are properly planted and cared for, they have a high survival rate. Growth is slow on poorly drained, droughty or alkaline soils. It is not vigorous in shady sites.

Multiflora rose should not be expected to make living fences on droughty sands or gravels, badly eroded claypan soils, alkaline soils, in wet sites or under shade.

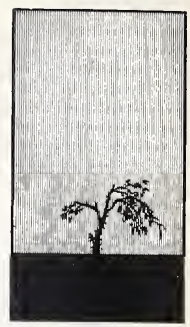

Poor Site

\section{Where to obtain planting material}

State Nurseries. Many of the State nurseries are now producing multiflora rose for farm plantings. Information and order blanks may be obtained from your County Agent.

Soil Conservation Service. Planting stock for some plantings may be made available through your Soil Conservation District. Call at the local office for information.

Private Nurseries. Watch the farm newspapers and magazines for advertisements. $\mathrm{Be}$ sure that the plants are the thorny variety!

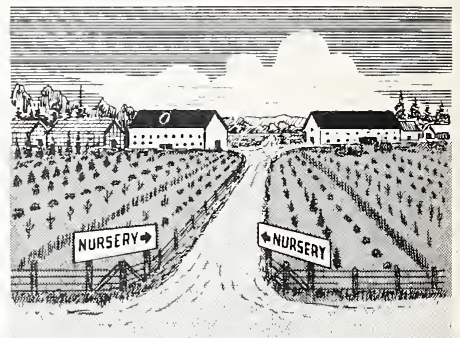

The State Department of Fish and Game in some states provides planting stock for planting on farms. Information can be obtained from the local Fish and Game Agent.

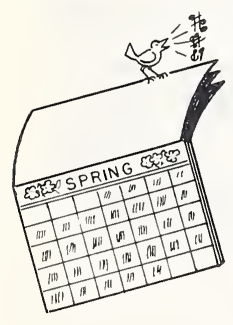

\section{When to plant}

Plant as early in the spring as possible. When the seedlings arrive, open bundles to prevent heating; keep roots moist and protected -- handle like tomato plants. If you can't plant for a day or two, place the plants in a shallow trench and cover the roots. When ready to plant, remove the seedilings from the trench and place directly in a pail of water. Keep the plants in the water until planted.

\section{How to plant}

Prepare the planting site in advance -- preferably the fall before planting. Plow one or two rounds with a double bottom plow - - and disk or drag. Planting in sod will not be successful. 
Replow and plant a single row in the furrow. Place the seedlings a foot apart. A handful of dirt will hold the plant in place and protect the roots until the next furrow covers.

Have the plow follow at the heels of the planter and cover the plants with another furrow to avoid exposing the roots to the sun. Pack the soil by foot or with tractor wheel driven alongside of the plant.

Where it is not convenient to use a plow for planting, the plants may be set by hand, using a shovel, spade or grub hoe.

Cultivate or mulch the rose for the first two or three years to control weed competition. Protect from livestock until a barrier is established. Manure or nitrogen fertilizer will increase the growth, particularly on wet or badly eroded soils. A complete fertilizer of a standard formula such as 5-10-5 is recommended. If the planting is to be irrigated, the water should be turned in at the time the adjacent fields are irrigated. The best plantings have been obtained under irrigation.

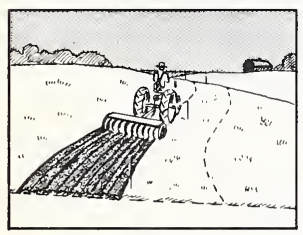

STEP 1

Disking Sod

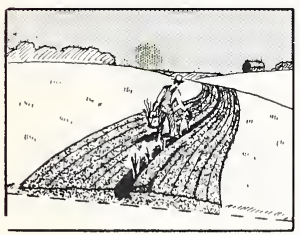

STEP 5

Plonting

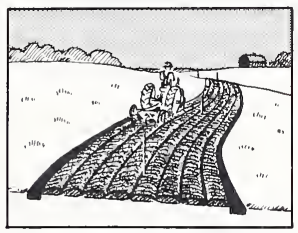

STEP 2

Plowing Site

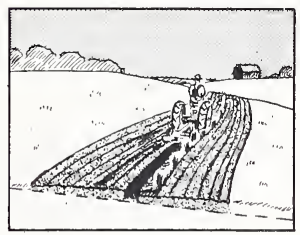

STEP 6

Filling Furrow

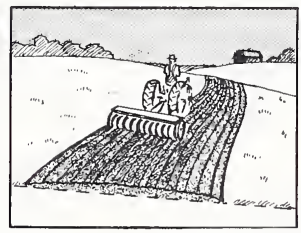

STEP 3

Disking Site

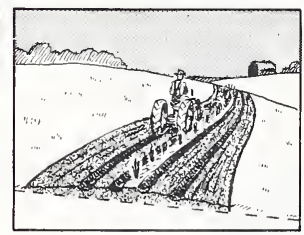

STEP 7

Pocking

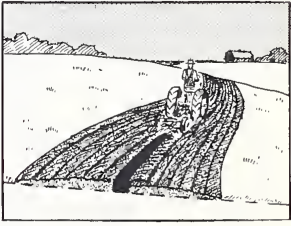

STEP 4

Plowing Furrow.

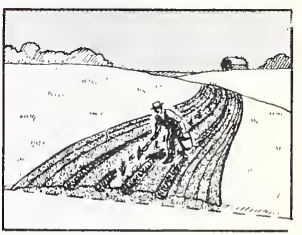

STEP 8

Fertilizing

\section{Where to plant}

Tests made by the Soil Conservation Service and State Departments of Fish and Game indicate that multiflora rose is adapted for use in the Pacific Coast area as shown on the shaded portion of the attached map. If your land is located in one of these areas, you can be reasonably assured of a successful planting. 


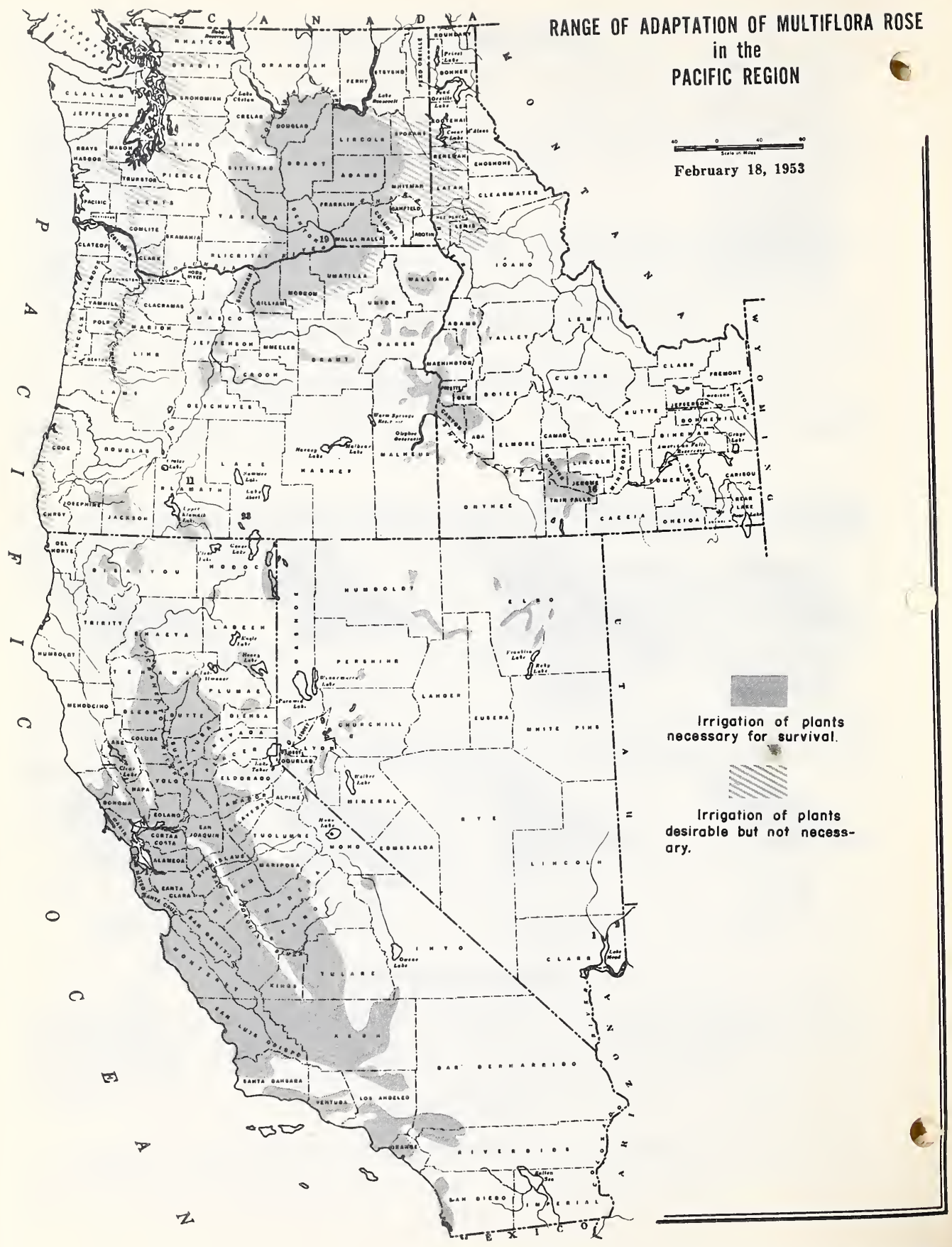




\section{UNITED STATES DEPARTMENT OF AGRICULTUHE}

SOIL CONSEHVATION SEKVICE

Pacific Region

Iand and rater Management

Biology Training Series \#4

WET LAND DEVELOPMENT FOR FUR AND WATERFONI PRODUCTION

I. Introduction

A. Much of the marshland in the Pacific Region is too wet for the production of cultivated crops or high-quality pasture. Before determining engineering and agricultural feasibility of drainage of these lands, consideration should be given to the profitable use of these lands in their natural state, for the production of furbearers such as muskrat.

B. Marshlands, wet areas and lands that can be inundated have been successfully developed as waterfowl breeding and hunting areas.

II. Development of marshlands for muskrats

A. Site X. Area supports natural stands of tule, cattail, bur-reed, sedges and other muskrat foods. Marsh may be partially or wholly inundated during wet season and dry during balance of year.

1. Develop by level ditching.

a. Establish ditches by dragline or shovel without grade throughout areas of marsh not covered by water entire year.

b. Depth of ditch - deep enough to prevent solid freezing; $2 \frac{1}{2}:-31$ of water in ditch.

c. Width of ditch $-2 \prime-31$ at bottom with $1: 1$ side slopes.

d. Place spoilbanks on alternate sic.es of ditch at intervals of $50^{\prime}$ - 100 to provide for waterfowl nesting and free movement of surface water.

0. Ditches should be spaced 200 apart for maximum return on investment. Connect each end or alternate ends.

f. Grazing livestock should be excluded from the area.

2. Ditches provide a natural access to forage areas by muskrats. The spoilbanks offer ideal den sites.

3. Under favorable conditions, a ditch should be constructed for $15 \%$ per cubic yaud $\left(\$ 15.00\right.$ per $\left.100^{\prime}\right)$. At this rate, the average per acre cost would be about $\$ 35.00$. 
4. Keturns. (Based on Wisconsin studies)

a.

\begin{tabular}{|c|c|c|c|c|c|c|c|}
\hline $\begin{array}{l}\text { Ditch } \\
\text { Spacing } \\
\text { in Feet }\end{array}$ & $\overline{1949}$ & $\frac{\text { Miusk }}{1950}$ & $\frac{\text { rat } H}{1951}$ & $\frac{\text { arves }}{1952}$ & $\frac{t}{\text { Total }}$ & $\begin{array}{l}\text { Yearly } \\
\text { Harvest } \\
\text { Per Acre }\end{array}$ & $\begin{array}{l}\text { Yearly Harvest } \\
\text { per } \$ 100 \text { invested } \\
\text { in ditching }\end{array}$ \\
\hline $\begin{array}{r}50 \\
100 \\
200 \\
400\end{array}$ & $\begin{array}{r}20 \\
53 \\
36 \\
12\end{array}$ & $\begin{array}{l}37 \\
77 \\
76 \\
35\end{array}$ & $\begin{array}{l}63 \\
74 \\
51 \\
30\end{array}$ & $\begin{array}{l}224 \\
213 \\
272 \\
172\end{array}$ & $\begin{array}{l}344 \\
417 \\
435 \\
249\end{array}$ & $\begin{array}{r}17.2 \\
10.4 \\
10.9 \\
6.2\end{array}$ & $\begin{array}{l}11.0 \\
12.4 \\
23.4 \\
24.6\end{array}$ \\
\hline Totals & 121 & 225 & 218 & 881 & 1445 & 10.3 & 15.4 \\
\hline
\end{tabular}

b.

INCONE:

100 feet 200 feet 400 feet

Sàle of pelts, @ \$1.47 each

Sale of carcasses, @ \$0.10 each I/

Total annual income

$\$ 152.88 \$ 160.23 \$ 91.14$

$\frac{10.40}{\$ 163.28} \quad \frac{10.90}{\$ 171.13} \quad \frac{6.20}{97.34}$

Less annual expenses (see belor)

Annual net income

$\frac{83.34}{79.94} \quad \frac{56.14}{\$ 114.99} \quad \frac{37.85}{\$ 65.49}$

Kate of interest earned on capital 2/ Heturn per hour of labor 3/

Average annual catch of muskrats

$10.2 \%$

4.26

104

$20.5 \%$
5.57
109

$21.3 \%$

5.64

62

EXPINSE:

Iabor, @ \$0.75 per hour 4/

Equipment depreciation 57

Taxes, @

Maintenance 6/

Interest, @ $4 \%$ of capital investment

Total annual expenses ?!

$17.16 \$ 17.98$

1.38

2.00

1.43

$\$ 10.23$

.78

\begin{tabular}{rrr}
12.34 & 6.83 & 3.70 \\
50.46 & 27.90 & 15.14 \\
\hline
\end{tabular}

2.00

2.00

\begin{tabular}{rrr}
12.34 & 6.83 & 3.70 \\
50.46 & 27.90 & 15.14 \\
\hline
\end{tabular}

$83.34 \$ 56.14$

is 31.85

CAPITAL INVESTMENT 8/

Ditching, (1) \$0.15 per cu. yd. or. $\$ 0.264$ per lin. ft.

$\$ 2,261.47 \$ 397.50 \quad \$ 378.41$

If Sold to mink ranchers as mink feed.

2) Net income $f$ interest charge capital invested $\times 100$

3/ Net income f labor charge $\div$ man-hours of labor.

4/ 0.22 man-hours per muskrat caught. 
5f Onemstop-loss trap (@ $\$ 0.75), 2$ No. $1 \frac{1}{2}$ traps (@ $\$ 0.35$ ), and 3 stretching boards (@ \$0.05) per 9 muskrats caught. Equipment estimated to have 20-year life; interest at $4 \%$.

6) Clean out of $8.3 \mathrm{cu}$. ft. of sediment per lin. ft. of ditch at end of 20 years, @ $\$ 0.25$ per cu. yd. Annual expense based on sinking fund @ $4 \%$ interest for 20 years.

7) In Wisconsin, add $\$ 2.50$ annually for fur farm license and \$0.01 per muskrat caught for required tags.

8) In Wisconsin, add approximately $\$ 22.50$ to cover purchase of original stock of muskrats from the State. Tisconsin law allows fur farm licensees to obtain permission to trap muskrats each year regardless of whether or not there is a general open season.

If it were necessary to purchase land on which to install level ditches, that cost should be added to capital investment.

B. Site $Y$. Well-drained or partially drained area supporting little or no marsh vegetation. Site adapted to inundation by diking systrem.

1. Develop by Hiking system and controlled water levels to convert area to marshland.

a. Maintain minimum water level of $6^{\prime \prime}$.

b. Increase depth of water in vinter if necessary to prevent solid freezing. Do not flood dens.

2. Exclude livestock from area.

3. Further study needed on this type of development.

III. Development of waterfowl breeding and/or hunting a reas.

A. Breeding and resting areas.

1. Natural ponds.

a. Exclude livestock from area.

b. Plant nesting cover (regular pasture mixture) around pond.

c. Erect resting boxes for wood-ducks where pond has wooded margins.

2. Artificial water areas.

a. Develop by diking system and controlied water levels or construct pond with shallow-rater edges.

b. Maintain water levels of $6^{\prime \prime}$ to $2^{\prime}$ in diked areas or shallow areas of ponds. 
c. Water level may be lowered folloring nesting season and exposed bottoms planted to wild millet, smartweeds, dwarf sorghums, etc. Reflood when seed has ripened.

d. Cover piantings of small bulrush may be introduced.

e. Plent nesting cover as in Ib above.

f. Protect area from grazing.

B. Hunting areas.

1. Best areas developed by diking system and controlled water levels.

2. Seed areas to wild millet, smartweeds, or dwarf sorghums.

a. Irrigate if necessary.

3. Flood areas to deptin of $4^{\prime \prime}-6^{\prime \prime}$ prior to hunting season.

4. Rotate use of areas every rear or two to prevent invasion of cattails and kulrush.

5. Plant area surrounding ponds to corn, sudan grass, etc. .

IV. Hecommended reference reading.

d. WATERFOTL MANAGENAN ON SMALI AREAS, Wildlife Management Institute, Washington, D. C.

B. PONDS FOK TILDIIFE, U.S.D.A. Farmers Bulletin No. 1879.

C. FUK FROM FAKM LANDS, Soil Conservation, Nay - June 1944.

D. EXPERTMEITAL LEVEL DITCHING FOR MUSKRAT MANAGEMENT, Technical Bulletin No. 5, Isccrsin Conservation Dept., Madison.

Paul M. Scheffer

Kegional Biology Division

August 1953 

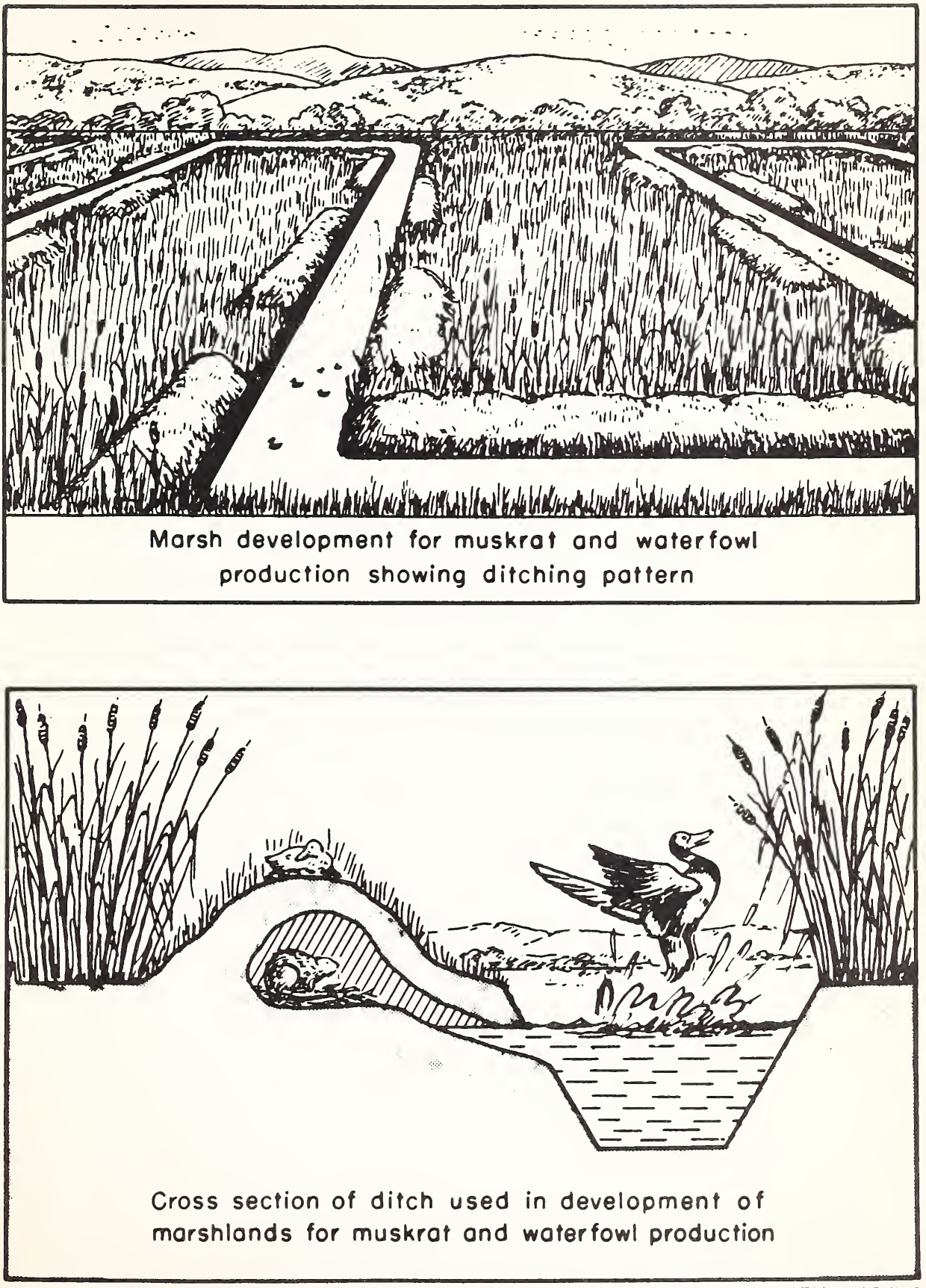
ei 


\section{UNITED STATES DEPARTMENT OF AGRICULTURE \\ SOIL CONSER VATION SERVICE \\ Pacific Region}

Land and Water Management

Biology Training Series \#I

DESIGNING A FARI POND FOR FISH PRODUCTION

I. Introduction

A. Most farm ponds constructed for irrigation water storage, livestock water facilities, and erosion or flood control are generally inadequate for the production of fish unless special attention is given to the design of ponds to be used for this purpose.

B. Farm ponds not designed for fish production generally have one or more of the following needs:

1. Erosion control on the watershed to prevent pond siltation.

2. Regulation of the amount of water flowing through the ponds.

3. Deeper water -- particularly at inlet and around the pond margin -- to discourage vegetative growth.

4. Fertilization to increase fish food supply and control aquatic weed growth and pond scum.

5. Provision for drainage of pond to permit restocking or repair.

6. Outlet structures designed to prevent fish loss.

7. Holding adequate water reserves for fish even when the water . level in irrigation reservoirs is low.

8. Fencing to exclude livestock.

C. Standard farm pond design features that are not specifically applicable to fish production problems are not included in this training outline.

II. Imporiant features of farm pond design for fish production:
A. Vater supply and control
B. Size
C. Depth
D. Outlets 
III. Farm fish pond water supply and control.

A. Source of water:

1. Springs

2. Clear streams

3. Irrigation ditches

(Safe water for trout must be within $\mathrm{pH}$ range of about 6 to 8.)

B. Flow of water through pond:

1. Constant flow may be desirable but not necessary.

2. Divert surplus water around pond.

(a) Headworks design

3. Pond $c$ an not be managed without full control of water.

4. Regulate flow to

(a) Maintain desired depths

(b) Maintain proper oxygen content

(c) Prevent solid freezing in winter

(e) Keep surface foot of water below these temperatures for trout - Rainbow - $75^{\circ}$, German Brown - $72^{\circ}-73^{\circ}$, Cuttbravat - $7 \complement^{\circ}$, and Eastern Brook $-65^{\circ}$. Bass and bluegill need water temperatures of $70^{\circ}$ or more for spawning.

IV. Farm fish pond size

A. Ponds less than $1 / 3$ acre will not support enough fish to af ford much food or sport.

B. Ponds of less than about 5 acres $c$ an be easily managed by one landowner.

C. Size of pond commonly determined by fish production needs:

1. A good trout pond should produce 80 to 100 pounds of $\mathrm{fish}$. per acre per year.

2. Well managed bass-bluegill ponds have produced $200-400$ pounds of fish per acre per year. 
V. Depth of farm fish ponds

A. A minimum depth of $8^{\prime}$ ( $10 \%$ or more of the pond) in cold winter climates.

B. Minimum of 61 in cool climates where little or no ice occurs.

C. In areas of warm summer climates, trout ponds must be deep enough to maintain minimum safe temperatures below the surface.

D. Irrigation reservoirs should not be drawn below $4^{\prime}$ depth.

E. Minimum depth for shoreline and any part of pond --31 . This is important from weed control standpoint!

VI. Pond outlets

A. Trickle tube

1. Eight inch minimum diameter vertical pipe draining into line through dam. This takes care of the small normal flow through the pond.

2. Trash free, escape proof screen may be installed.

B. Emergency spillway

1. Needed on all ponds where full control of water flow to pond is not obtained.

2. Design spillway wider than necessary to prevent fish loss. Fish avoid shallow depth and slower current in the wider opening.

3. Do not screen the spillway!

VII. Pond protection

A. Exclude livestock. Fence pond and provide stock tank outside of area.

B. Plant grasses, trees and shrubs to improve area for wildlife.

VII. Recommended reference reading:

A.

Current. Handbook of engineering practices, Soil

Conservation Service, Pacific Region.

B. Compton, Lawrence V.

1943. Techniques of fish pond management.

USDA Miscellaneous Publication No. 528. 
Biology Training Series $\# 1 \quad-4-$

IIII. Recommended reference reading (continued)

C. Davison, Verne E.

1945. Farm fish ponds for food and good land use. USDA Farmers' Bulletin 1983.

D. 1953. How to Build A Farm Pond for Fish Production.
Job Sheet. SCS. Pacific Region.

Paul M. Scheffer

Regional Biology Division July 15,1953 
These very important features of farm pond design should be considered if you want to produce fish in your pond:

1. Water supply and control

2. Size

3. Depth

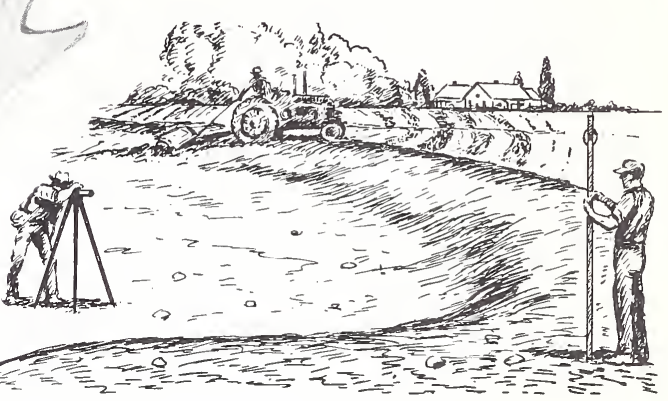

4. Outlets

\section{WATER SUPPLY AND CONTROL}

A steady flow of water through your pond is not necessary - particularly if you add fertilizers to the water to increase the food supply for fish. If you have a constant supply of water, such as from a spring or stream, you should regulate the flow to the fertilized pond. Put only enough water in the pond to maintain the desired water level and temperature. Regulate the flow of water through your pond by diverting the surplus water through an open ditch around the pond. (Figure 4.)

\section{SIZE AND DEPTH OF POND}

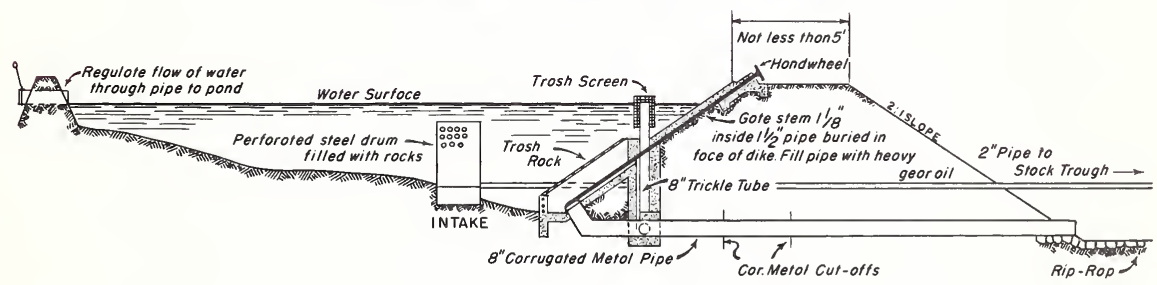

FIGURE 1.- Section thru pond showing water control and out let structures.

Farm ponds to be used for fish production should have a water surface of not less than one-third of an acre.

Make your pond at least 8 feet deep at the deep end. In areas of cold winter climate, a pond should be 10 to 12 feet deep or have enough flow of water through it to prevent winter kill. This depth will ordinarily provide for sufficient water under the ice for fish. If the water level will be as low as four feet in dry seasons, the ponds should be deep enough when full to provide for this safe depth margin. 
To prevent growth of willows, bulrush, cattail and other undesirable plants, no part of your pond should be less than one and one-half to three feet in depth.

If you irrigate from your pond, do not draw the water lower than a fourfoot depth. Unless your pond is refilled within a few days, the water will become too warm for trout. If the water level is to be low for a long period, you should stock with bass, bluegill, catfish, perch, or other warm-water species.

\section{DESIGNING THE POND OUTLET}

Make the outlet large enough to safely dispose of flood waters and yet prevent excessive loss of fish during storm periods.

A farm pond usually needs two outlets. One outlet - - a "trickle tube"' - will take care of the small normal flow through the pond. If necessary, this outlet may be screened to prevent fish loss. (Figure 2.) Unless the flow of water to your pond can be controlled at the headworks, you should install a second outlet to take care of flood waters. This is the emergency spillway. Never screen this outlet. A clog with debris and endanger the dam.

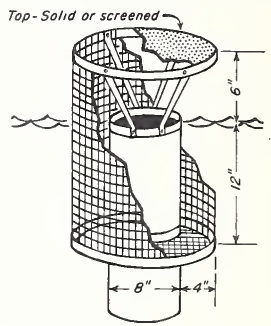

FIQURE 2.- Trash-free screen for Trickle

Tube outlet.

The trickle tube outlet is a vertical pipe -- concrete or corrugated galvanized iron - leading into a line through the base of the dam. (See Figure 1.)

The emergency spillway is usually installed on undisturbed soil at one end of the dam. (Figure 4.) If this spillway can be built wider than necessary to take care of flood waters, the fish loss will be reduced during storm periods. This is because of the shallower depth and slower çurrent in the wider opening.

You should have an engineer determine the size of the trickle tube and spillway.

Install a drain on the line through the dam. (See Figure 1.) This will allow you to completely drain the pond when it is necessary for you to restock the pond with fish or to repair the pond structures.

\section{AVOIDING WEED GROWTH IN POND}

To keep the pond free of cattails and other weed growth, the margins of the pond should slope steeply to a 1-1/2 to 3-foot depth. (See Figure 3.) The water is too deep at this level for most plant growth. Some of the pond weeds will persist, however, even in six feet of water. Shallow water at the inlet may be avoided by dyking off this area. (Figure 4.)

If you want good fishing, do not permit vegetation to grow around the shoreline of the pond or in the pond itself. Fishing is poor where such growths are permitted. Pond scum also forms around the plants and eventually covers the pond. Important, too, is the mosquito problem in ponds not kept free of plant growth. Fish cannot keep a weedy pond free of mosquito larvae. 


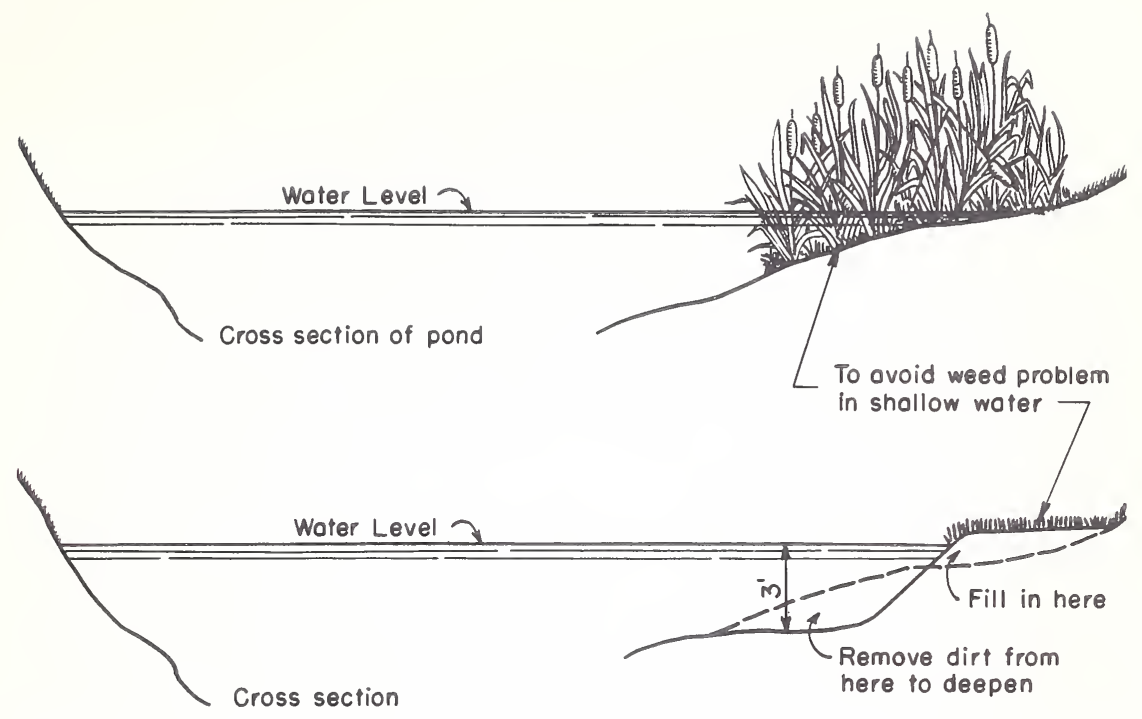

FIGURE 3.- Pond edges should be deepened to control emergent water plants and improve fishing.

\section{LANDSCAPING THE POND FOR WILDLIFE}

Many kinds of game birds, waterfowl and other wildlife will come to your pond for water. You can make the pond site more attractive to wildlife by planting grasses, trees and shrubs around the area back from the shoreline. Protect the pond area from livestock whether or not you develop it for wildlife. A suggested pond layout design is given in Figure 4.

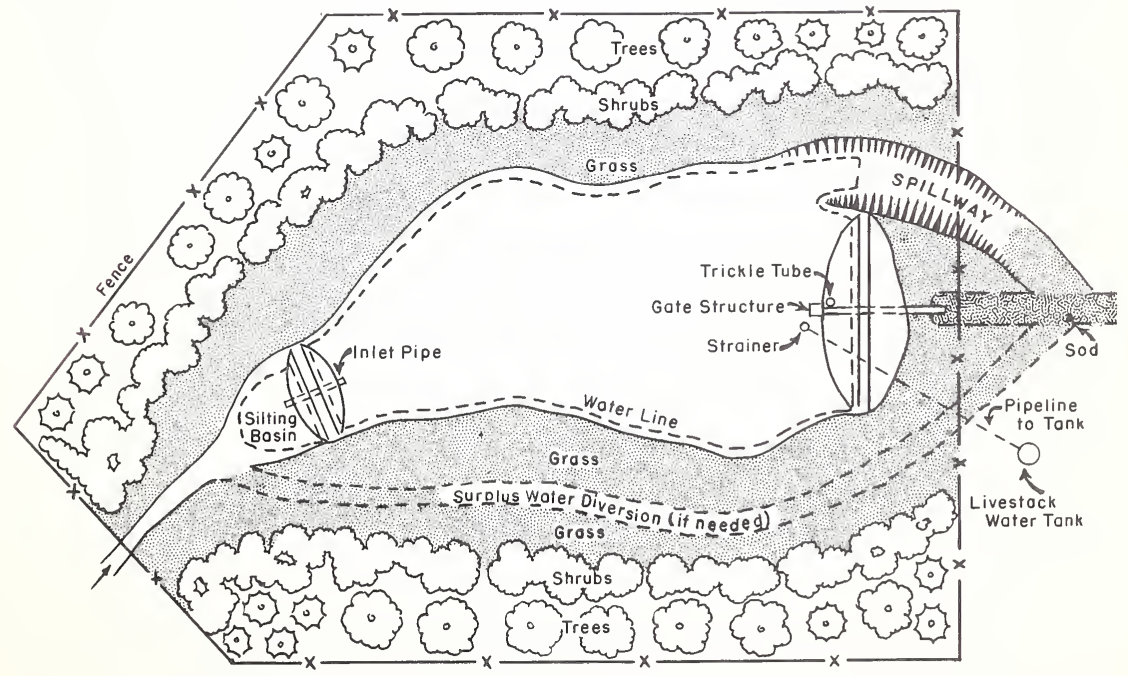

FIGURE 4.- Farm pond lay-out showing location of structures and wildlife planting areas. 
Engineering help of the Soil Conservation Service may be obtained from your Soil Conservation District on the following:

1. Location of suitable pond site.

2. Determining suitability of soil for holding water and building earth-fill dam.

3. Determining adequacy of water supply.

4. Designing all structures -- dam, inlet control, trickle tube outlet, emergency spillway, stockwater facilities, etc.

5. Technical direction of construction.

\section{WHERE TO GET HELP}

Arrangements for help in the stocking and management of your pond for the production of fish can be made through your Soil Conservation District. In some states, this assistance is provided by the State Fish and Game Department.

The office address of your Soil Conservation District is --

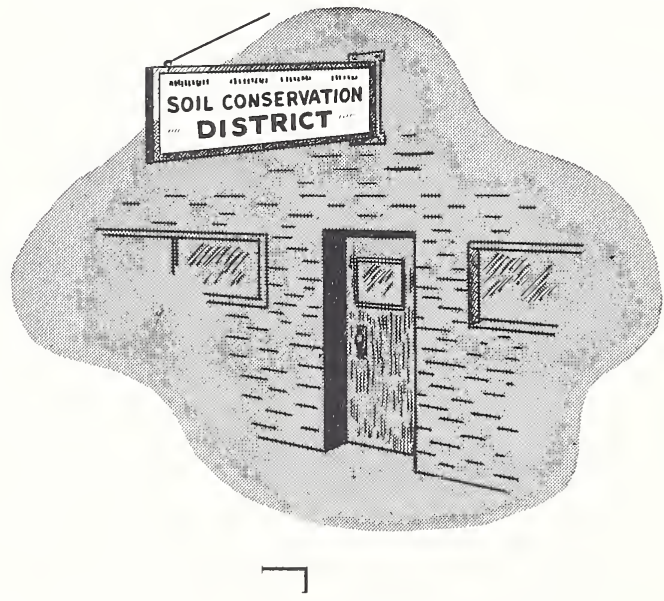

This leaflet prepared by U.S.Department of Agriculture, Soil Conservation Service in cooperation with the State Fish and Game Departments of Oregon, Idaho, California and Nevada. 
Land and Water Management

Biology Training Series \#3

MANAGING A FARM POND FOR BASS AND BLUEGILL PRODUCTION

I. Introduction

A. Pound for pound, acre for acre, a properly managed farm pond will out-produce the average pasture.

1. Bass-bluegill production -- 200 to 400 pounds per year, per acre. Fish dress out about $65 \%$ of live weight.

2. Beef production -- 150 pounds per year. Beef will dress out at $55 \%$ of live weight.

3. An acre of water may produce 250 pounds of clean fish; an acre of pasture 85 pounds of beef.

II. The important essentials of pond management for bass and bluegill production include:

A. Proper design and construction of pond.

B. Adequate water supply and control of flow.

C. Proper stocking.

D. Management of water.

III. Design and construction of farm pond

A. Follow specifications and design recomendations included in:

1. HANDBOOK OF ENGINEERTHG PRACTICES, SCS, Pacific Region.

2. Job sheet, HOW TO BUILD A FARM POND FOR FISH PRODUCTION, SCS, Pacific Region.

IV. Proper stocking

A. Large-mouth bass and bluegill are probably the most satisfactory species for stocking warm-water ponds.

B. Bass and bluegill stocking rate and carrying capacity of pond is determined by:

1. Surface area of pond.

2. Quality of pond.

3. Management practices proposed.

4, Size of the fish. 
Biology Training Series $\# 3$

C. Standard bass and bluegill stocking rates per surface acre of fertilized water:

1. 100 bass and 1,000 bluegill fingerlings.

D. Bass and bluegill stocking rates, for non-fertilized ponds.

1. About one-half of above rates.

2. The stocking rate for bass and bluegill in shallow ponds and ponds with considerable fluctuation in water level should be from $1 / 10$ to $1 / 3$ the standard rate.

E. The stocking rate for irrigation reservoirs is 50 bass and 500 bluegill per surface acre figured at the lowest level of the reservoirs.

F. Planting directions:

1. Do not expose fingerlings to sudden change in water temperature, $\mathrm{pH}$ or dissolved $\mathrm{O}_{2}$ or $\mathrm{CO}_{2}$.

2. Set container $(1 / 2$ full) in pond; gradually add pond water for 15 to 20 minutes until container is full; release fish slowly.

G. Time of stocking

1. Bass and bluegill may be stocked at the same time or bass may be stocked in the next spring following introduction of bluegill. If the latter stocking plan is followed, the bass stocking should not be delayed beyond vay or June.

2. Stock bluegills as early in the summer as they can be obtained. 
V. Management of water

A. Practical system of pond management is based on "food chain".

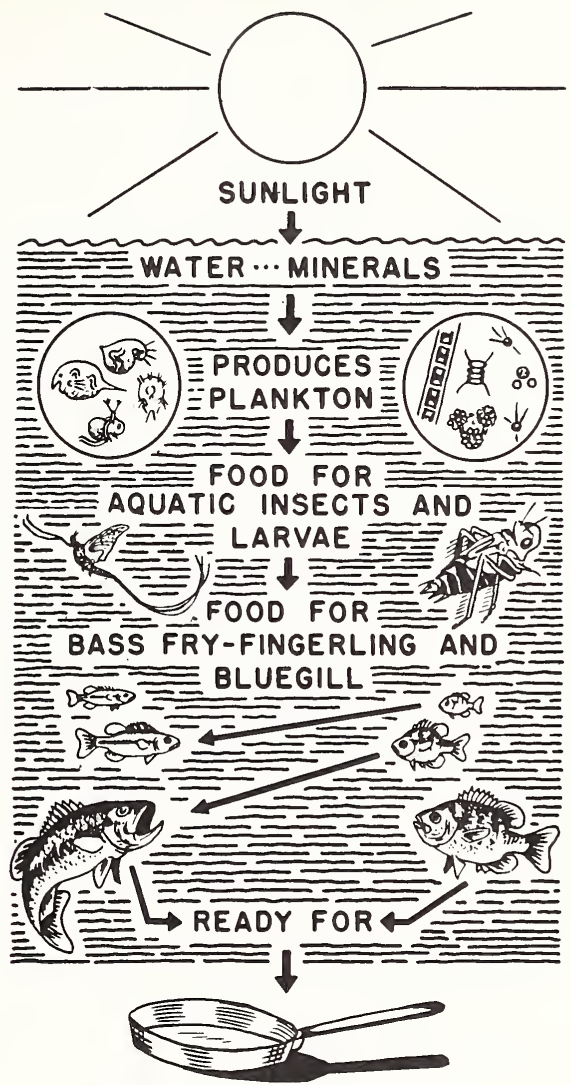

B. Food chain illustrates:

1. Carrying canacity。

2. Danger of overstocking.

3. Danger of mixing species.

4. One reason for "good" and "poor" fishing.

C. Fish require about 5 pounds of food to increase 1 pound in weight. 


$$
+1
$$


D. Fertilization of the water increases the production of insects and other aquatic life upon which bass and bluegill feed.

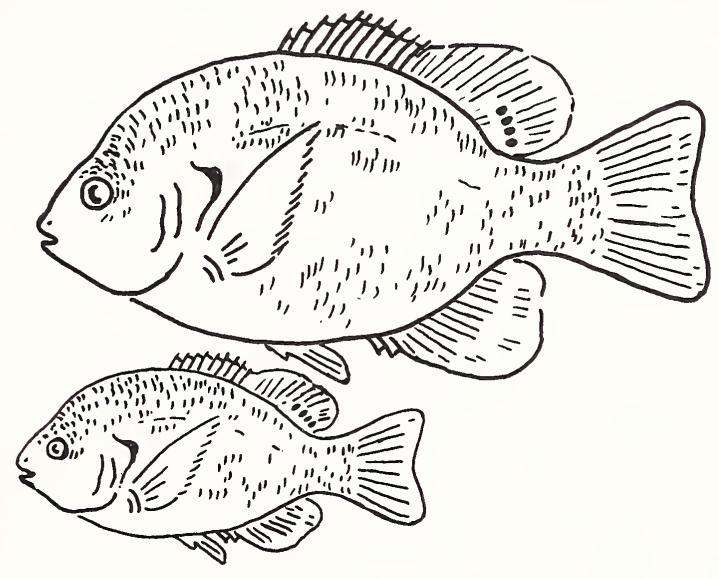

Effect of fertilization on size of fish.

Upper - Average size ( 4.0 ounces) in a fertilized pond. Lower -- Average size ( 1.1 ounces) in an unfertilized pond. Both ponds were stocked with 1500 bluegills per acre.

E. Fertilization promotes growth of plankton that clouds water and shades out undesirable water weed growths.

F. Fertilization of water in areas of hot summer climates is in test stage. 
$\therefore .$.

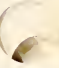

6 
Biology Training Series

G. Application of fertilizer:

1. Use fertilizer mixtures $8-8-2,8-8-4,10-10-5$, or 12-12-6.

2. Apply at rate of 100-200 pounds per surface acre.

3. Begin application in early spring. Continue applications as often as necessary to keep water cloudy. Do not use fertilizer after fall frosts.

4. Commercial fertilizer may be applied by pouring it over the side of either a motor or row boat, or it can be spread from the windward side from the shoreline by broadcasting in water 18 inches or more in depth.

VI. Management of the fish

A. Information concerning reproduction of bass.

1. Bass spawn once a year beginning at age of 10 to 12 months if weight of 5-6 oz. has been obtained.

2. A water temperature of about $70^{\circ}$ is necessary for successful spawning.

3. Fingerling bass should be stocked in the late summer or fall if they are to reach spawning condition by the next summer.

4. Large bass fail to sparm unless they have adequate supply of small fish for food in winter and spring months.

B. Information concerning reproduction of bluegill.

1. Bluegill spawn at intervals throughout the summer beginning at about $I$ year in age and $1 \mathrm{oz}$. or more in weight.

2. Fingerling bluegill are commonly stocked a year ahead of bass.

3. The spawning activities of bluegill can be used as an indication of pond balance.

a. If little or no spawning occurs, the pond is overcrowded and bluegill fishing is poor.

b. If spawning occurs at intervals throughout the summer, the pond is usually in balance and fishing it at its best.

C. Fishing.

1. Begin fishing after both bass and bluegill have spawned the first time.

2. The best fishing is from ponds that are fished regularly and heavily. 


\section{Biology Training Series \#3}

a. Bass-bluegill ponds cannot be overfished.

b. Year around fishing is recommended unless prohibited by state law. It is not necessary to protect the fish during spawning periods.

c. Remove any fish from pond, regardless of size, that are caught. (Check state laws).

d. The pond should be drained and the fish populations rebalanced, if necessary. Balancing by use of adult bars, introduction or partial poisoning is "tricky".

VII. Techniques for analyzing relative fish life balance in farm ponds

The pond analysis system is mainly based on the reproduction of bluegill. If little or no bluegill reproduction and no small bass can be found it may be concluded that the numbers of bass in the pond are not sufficient to keep the bluegill from over-populating the pond. An over-population of bluegill results in reduced spawning or none at all. If no bass reproduction is observed it is usually a sign that there are too many bluegill. The bass reproduction is thus checked by the bluegill who are forced to eat the bass spawn. Lack of bass reproduction in a newly stocked pond may also be attributed to the absence of sufficient food for the bass to reach their 6 ounce spawning size. If both bass and bluegill reproduction is found in a pond it may be concluded that the fish life is in proper balance.

A simplified outline of the pond analysis system is given below.

A. Both bass and bluegill reproduction found in pond during July and August in the second year (or years thereafter) after stocking.

Conclusion: The ratio between the bass and bluegill is proper and the pond is in correct belance.

Correction: None needed.

B. Little or no bluegill or bass reproduction in pond.

Conclusion: Either there are no bass or not sufficient bass in the pond to prevent bluegill from becoming over, crowded.

Correction: Introduce bass at standard stocking rate of 100 per surface acre.

C. No bass reproduction in pond.

Conclusion: This condition can be attributed to one of the following: (a) There is an over-population of bluegill in the pond and they are forced to eat the bass eggs, (b) There is an over-population of bass in 
Biology Training Series \#3

the pond which results in a food supply insufficient to allow the bass a rapid growth to the 6 ounce spawning weight.

Correction: For (a) above -- seine as many of the bluegill as possible from the pond and restock with bass (100 per surface acre) and increase fertilization. For (b) above -encourage heavy bass fishing and keep all bass caught regardless of size.

VIII. Obtaining fish for stocking purposes

A. Licensed private hatcheries.

1. Refer to POCKET HANDBOOK for list of hatcheries in your state.

B. State hatcheries.

1. Fish hatcheries operated by some State Fish and Game Departments provide fish for stocking farm ponds in the state.

2. Other states may stock large ponds (25 surface acres or more) if a part of the pond is open to public fishing.

IX. State laws

A. Permits are required for the stocking of farm ponds with fish in all states. Obtain permits from State Fish and Game Department.

B. Fishing seasons and limits for farm ponds vary from state to state. Have cooperators check with local State Fish and Game Agent.

X. Reference reading

A. FARM FISHPONDS, U.S.D.A. Farmers Bulletin 1983.

B. TECHNIQUES OF FISHPOND MANAGEMENT, U.S.D.A. Miscellaneous Publication No. 528 .

C. HOMEMADE FISHING, Verne E. Davison, Telegraph Press, Harrisburg, Penn., 1953.

D. SYMPOSIUM OF FARM FISHPONDS AND MANAGENENT, Isurnal of Wildlife Manasement (Reprint), Vol. 16, No. 3, July 1952.

E. HOW TO MANAGE A FARM POND FOR WARM-WATER FISH PRODUCTION, S.C.S., Region 7, Job Sheet (Proposed). 
$e$ 


\section{UNITED STATES DEPARTMENT OF AGRICULTURE \\ SOIL CONSER VATION SER VICE \\ Pacific Region}

Land and Water Management

Biology Training Series \#2

MANAGING A FARM POND FOR TROUT PRODUCTION

I. Introduction

A. An acre of properly managed farm pond water will about equal the production of meat (trout) that may be obtained from an acre of well-kept pasture. Pound for pound, acre for acre, a managed pond will out-produce poor pasture.

1. Trout production -- 80 to 100 pounds per year, per acre. Trout dress out about $65 \%$ of live weight.

II. The important essentials of pond managenent-for trout production include:

A. Proper design and construction of pond.

B. Adequate water supply and control of flow.

C. Proper stocking.

D. ivanagement of water.

III. Design and construction of farm pond

A. Follow specifications and design recommendations included in

1. HANDBOOK OF ENGINEERIIVG PRACTICES, SCS, Pacific Region.

2. Job sheet, HOW TO BUILD A FARM POND FOR FISH PRODUCTION, SCS, Pacific Region.

I.V. Water supply and control of flow

A. Supply

1. Source of water should be cool enough to maintain surface-foot temperatures below --

$75^{\circ}$ for rainbow trout

$72^{\circ}$ - $73^{\circ}$ for Geman brown trout

$70^{\circ}$ for cut-throat trout

$65^{\circ}$ for eastern brook trout

2. Source of water should be within $\mathrm{pH}$ range of 6 to 8 . 
IV. Water supply and control of flow (continued)

3. Water supply should be free of silt and other foreign material.

B. Control of water flow uhrough pond

1. Constant flow of water may be desirable but not necessary.

2. Pond can not be managed without full control of water.

3. Regulate flow to:

a. Maintain desired depths

b. Maintain proper oxygen content. (Minimum safe limit about 4 parts per million.)

c. Prevent solid freezing in winter.

d. Maintain proper safe temperatures for fish.

V. Proper stocking.

A. Rainbow trout probably the most satisfactory species for stocking ponds.

B. Trout stocking rate or carrying capacity of pond is determined by:

1. Surface area of pond

2. Quality of the pond

3. Management practices proposed

4. Size of the fish

C. Standard trout stocking rates per surface acre of fertilized water.

1. 350 fry or

2. 300 fingerlings or

3. 50 adults.

D. Trout stocking rates for non-fertilized ponds.

1. About one-half of above rates. Rate may be increased if source of water supply is rich in natural foods.

E. Trout stocking rates may be increased by use of supplintintal feed. This rate is yet to be determined. 


\section{Biology Training Series \#2 - 3 -}

V. Proper stocking (continued)

F. Planting directions

1. Do not expose fry or fingerlings to sudden change in water temperature, $\mathrm{pH}$ or dissolved $\mathrm{O}_{2}$ or $\mathrm{CO}_{2}$.

2. Set container ( $1 / 2$ full) in pond; gradually add pond water for 15 to 20 minutes until container is full; release fish slowly.

G. Restocking

1. Trout do not spawn in ponds.

2. Restocking may be accomplished by (a) replacing trout caught by purchase of new stock, or (b) establishing spawning beds in streams supplying water to the pond.

3. Artificial restocking

a. Annual stocking at initial rate gives steadier fishing but smaller fish.

b. Restocking every other year may be done in pond not intensively fished. Allows more g rowth of fish.

c. Do not restock with fry or fingerlings until most of large trout have been caught.

4. Spawning.

a. Spawning beds"may be established in cold streams supplying water to pond.

b. A bed for an acre of pond weter should be about 75 square feet $-25^{\prime}$ long by $3^{\prime}$ wide.

c. Spawning bed should contain about 1 foot of coarse sand.

d. Flow of water over beds should be 10" deep.

VI. Management of water

A. Practical system of pond management is based on "food chain". . (See illustration on following page.) 
VI. Management of water (continued)

"Food chain"

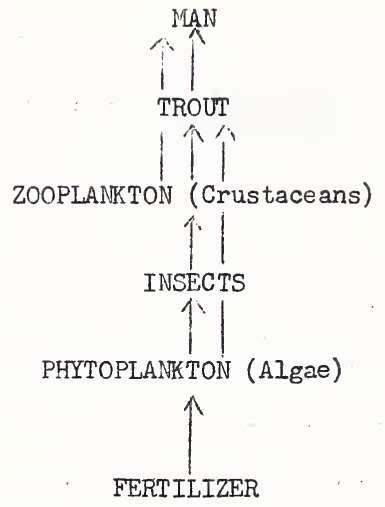

B. Food chain illustrates:

1. Carrying capacity.

2. Danger of overstocking.

3. Danger of mixing species.

4. One reason for "good" and "poor" fishing.

C. Fertilization of the water increases the prodition of insects and other aquatic life upon which trout feed.

D. Fertilization promotes growth of plankton that clouds water and shades out undesirable water weed growths.

E. Application of fertilizer:

1. Use fertilizer mixtures $8-8-2,8-0-i ; i j-10-5$, or $12-12-6$.

2. Apply at rate of $100-200$ pounds per ace acre.

3. Begin application in early spring. Vontinue applications as often as necessary to keep water cloudy. Lo not use fertilizer after fall frosts.

VII. Obtaining fish for stocking purposes

A. Licensed private hatcheries

1. Refer to POCKET HANDBOOK for list oi hatcheries in your state. 
Biology Training Series \#2 - $5-$

VII. Obtaining fish for stocking purposes (continued)

B. State Hatcheries

1. Fish hatcheries operated by the Idaho State Fish and Game Department provide fish for stocking farm ponds in the state.

2. Other states may stock large ponds ( 25 surface acres or more) if the pond is opened to public fishing.

VIII. State laws

A. Permits are required for the stocking of farm ponds with fish in all states. Obtain permits from State Fish and Game Department.

B. Fishing seasons and limits for farm ponds vary from state to state. Have cooperators check with local State Fish and Game Agent.

Paul M. Scheffer

Regional Biology Division

July 15, 1953 
STockine Unless your pond is unusually cold, you probably will be more satisfied with Rainbow Trout than any other kind of trout. Rainbows are the hardiest and most disease-resistant of any of the trout, and are usually the easiest to obtain.

Do not stock bass, bluegills, or any other kinds of fish with trout.

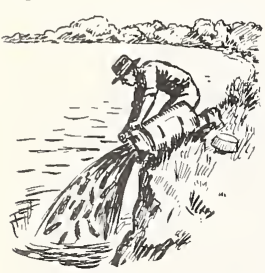

If there are other fish already in the pond, they should be removed before stocking with trout. Trout should be stocked at the rate of 300 to 500 fingerlings or 50 adult fish per surface acre of water. These rates are for fertilized ponds.

Rainbow Trout do not reproduce in ponds; they must be restocked periodically.

FERTILIME Fertilizing pond waters will increase

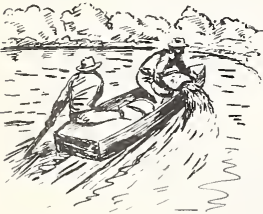
the production of insects and other aquatic life upon which trout feed. The hand feeding of $f$ ish is not necessary in a fertilized pond. Also important, fertile waters are cloudy with a tiny plant life that shades out undesirable water weeds.

Fertilizer should be applied early each spring, followed by applications at two-week intervals until the water becomes so cloudy that you cannot see bottom in $1 \cdot 2$ to 14 inches of water. Additional applications should be made until fall frosts whenever the water becomes clear. In areas of hot summer climate, it might be found desirable to discontinue fertilization during June, July, and August in order to maintain a higher oxygen content in the water.

Each application of fertilizer should consist of 100 to 200 pounds per surface acre. The best fertilizer formulas are 8-8-2, 8-8-4, $10-10-5$. or 12-12-6.

If filamentous algae (pond scum) develops on the pond surface, the source of the scum should be eliminated before discontinuing fertilizer applications. The scum usually forms in grass, weed or marsh-plant growth in the shallow water and spreads over the pond. If such vegetation is removed, the trouble with scum will be considerably reduced.
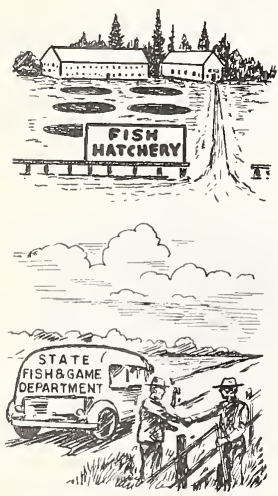

WHERE TO GET FISH Fish for stocking private ponds usually must be obtained from private hatcheries. Some State Fish and Game Departments also provide trout for stocking farm ponds. Your Soil Conservation District maintains an up-to-date list of all of the licensed private hatcheries in the State. Your own arrangements for purchase and delivery of the fish can be made with the hatchery operator.

REGULATIONS Most states have regulations governing the planting of $f$ ish in private ponds. Permits are usually required. To be on the safe side, you should check with the local Fish and Game Department official before making arrangements to stock your pond. 


\section{FISH IDENTIFICATION}

These sketches will be helpful in the identification of fishes commonly found in farm ponds in the "estern States.
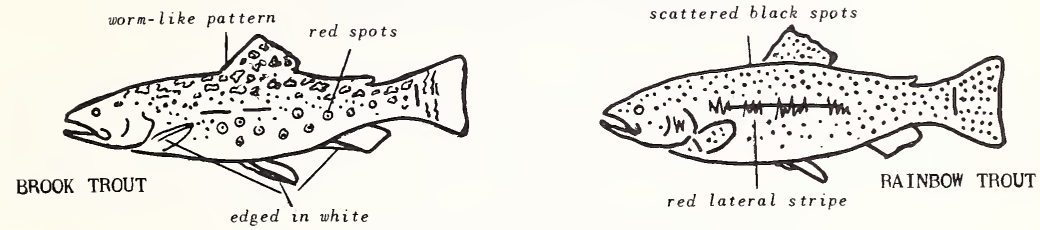

dark spots
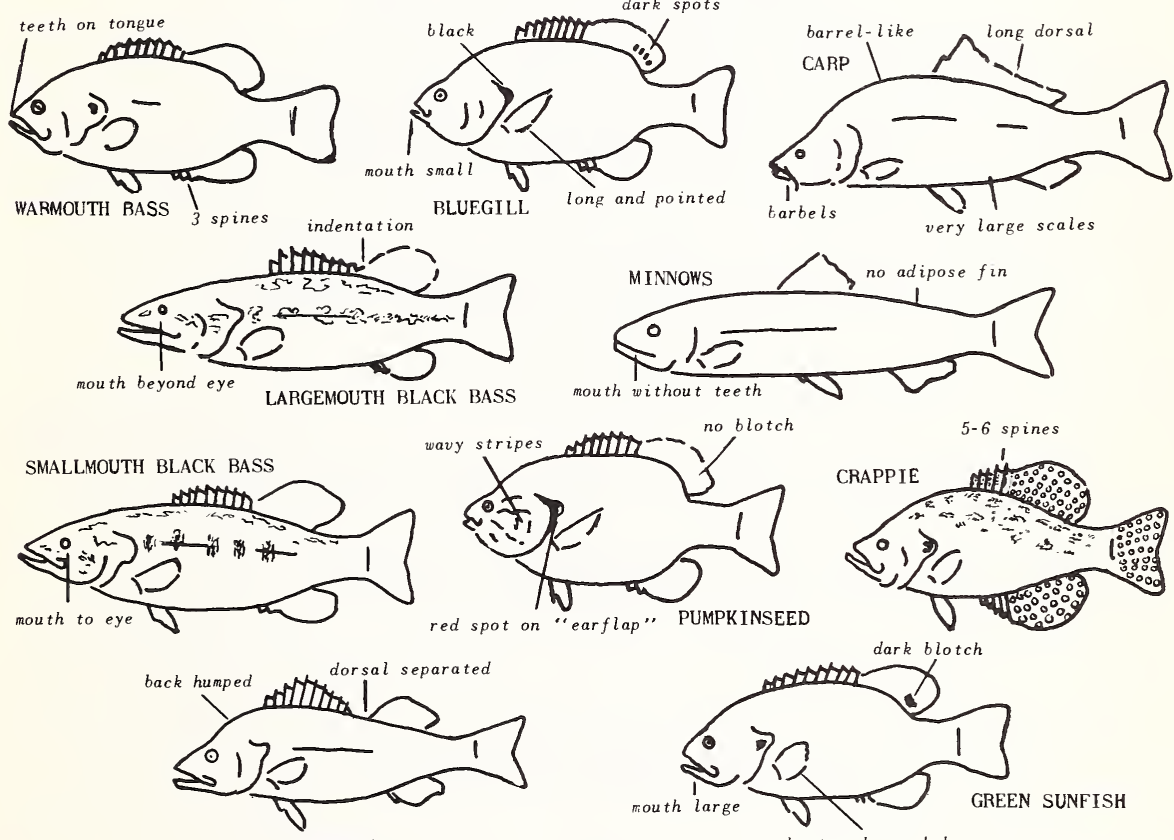

YELLOW PERCH

$$
\text { 7-8 spines }
$$
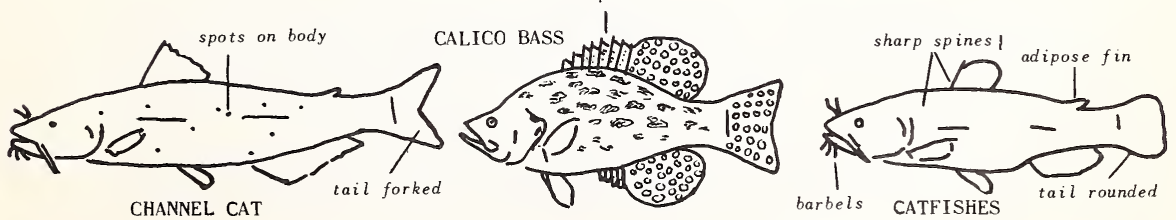
6 


\section{UNTTED STA TES DEPARTIENT CF AGRICULTURE \\ SOIL CONSERVATION SERVICE}

Land and Water Management

Biology Training Series 6

THE CHEMICAL CONTROL OF SUBIERSED AQUATIC

PLANTS IN FARM PONDS AND RESERVOIRS

A large variety of chemicals have come into use in the control of algae, (pond scum) pond weeds and other submensed aquatic plants. At le ast two of the chemicals, copper sulfate and sodium arsenite, have been effective in the control of such plant growth without endangering fish life.

\section{How to Calculate Required Dosage}

Both copper sulfate and sodium arsenite are applied at rates proportionate to the volume of water in the pond or reservoir. In order to determine the volume of water to be treated, multiply the average length of the water irnpoundment by the average width. This will give the surface area in square feet. This area multiplied by the average depth (obtained by souridings) gives the volume of water in cubic feet.

Note: 1 cubic foot of water contains 7.48 gallons; 1 cubic foot of water weighs 62.4 pounds; I pound of chemical per million pounds of water equals $I$ part per million.

\section{Copper Sulfate}

Rate of Application

For treatment of entire body of water -- 1.0 part per million (8.3 pounds per million gallons of water).

For spraying on surface-floating pond scum only - $11 / 4$ standard measuring cups of powdered copper sulfate to 5 gallons of water in the spray mixture。

\section{Margin of Safety to Fish}

Pond fish can withstand concentrations up to 1.2 parts per miliion in soft water. The limits are much higher in hard water.

How to Mix and Apply

In mixing and applying copper sulfate, a painted galvanized tub, wooden tub or crock may be used. Copper sulfate may be dissolved in a tub of water and the chemical solution broadcast by hand from a boat by the use of a long-handled en amel dipper.

In direct application to surface-forting pond scum, a copper sulfate solution is applied with powered or hand spray apparatus. 
Note: Sodium arsenite is more effective than copper sulfate on thick pond scum growths or where the growth covers a large part of the pond surface.

\title{
When to Apply
}

The use of copper suliate in algae contro is most effective in the early stages of growth of the plant.

A.1. patches of algae should be sprayed when they first appear on the surface of the pond. Periodic sprayings during the hottest part of the day will give effective control.

upecies of Weeds Contzolled

Pond scum algae (Hycrodictyon, Oedogonium, etc.) Huskgrass (Chara)

\author{
Sodium Arsenite
}

Kate of Application

During warm summer months, 4.0 parts per million will kill even the most dense growths of submersed aquatic plants in both hard and soft water. Where weeds are not too dense, 2.5 parts per million will generally give good results.

Margin of Safety to Fish

Sodium aisenite has a wide margin of sefety as a hazard to fish since ebout 11.0 to 12.0 parts per million are required to kill them. However, where vegetation is very dense, care must be taken in the use of sodium arsenite to avoid the destruction of fish through too rapid decomposition of the trested vegetatjon. In ponds in midsummer, the critical period for fish occurs about two or three days after treatment when the plants, which have fallen to the bottorn, begin to decay rapidly and use up the oxygen which is also necessary to maintain fish life. In ponds with supply pipes, a moderate amount of water can be turned in two or three days following treatment. In ponds without an inflow, it is recommended that only a section of the pona be treated at one time. In case of an emergericy, aeration may be accomplished by pumping and spraying the water back into the pond.

How to Mix and Apply

The sodium arsenite is diluted or dissolved in water, depending on whether it is in liquir or powder form. In either case the material should be stirred thoroughly with a stick or a paddle. The powder must be completely dissolved before introduction into spray tanks; otherwise it will settle on the bottom of the tank and will not be dispersed. The sodium arsenite solution should be sufficientily diluted with water to obtain thorough coverage of the pord. The more it is diluted, the better the coverage. 
The operator should wear rubber gloves while mixing in order to avoia getting sodium arsenite solvtion in open cuts on his hands. Protective covering may be used to prevent damage to clothing.

The simplest method of application of both forms of sodium arsenite is by distribution from an unpainted tub placed in the front end of the boat. The sodium arsenite solution is broadcasi from the tub in the front end of the boat by means of a long-handled enamel dipper. With some practice, the solution may be distributed in almost a spray-droplet size by giving a quick jerk to the handle of the dipper as the solution is being broadcast. This method serves well in small ponds up to about an acre in area.

In larger ponds, a tree sprayer and pressure tank is recommended. The tank, which may be a wide, squat type to avoid tipping in a truck or boat, is provided with an air connection to a gasoline-driven air compressor, and handles for lifting the tank in and ont of the boat. The tank should nave a gauge which wili enable the operator to see how much liquid remains. In applying the chemical, the tank is parily filled with water before the sodium arsenite solution is introduced into it. The tank is then filied up to within a short distance of the top and its contents mixed. An air space is aliowed at the top of the tank icr air compression. The spray is applited under a pressure of 40 to 60 pounds to the square inch.

ineri to Apply

The best results are obtained in warm weather before the weeds have madt full growith.

qutions Regarding Use

Sodium arsenite is a caustic poison and should be handled and used accordingly.

Cattle and other grazing animals should be excluded from the pond area for a period of from one to two weeks after spraying. Special care should be taken to prevent the spilling of the concentrated solution on above-water weeds where grazing may occur.

ivecies of Weeds Controlled

The use of sodium arsenite as outlined will kill the floating leaves of iilies, but it rarely kills the roots. It is not recommended for the cortrol of cattails or bulrushes. It does not destroy Chara (miskgrass); a plant which may be identified by its stiff habit of growth, its sharptipped branches and its pungent musty odor. Pond scum when in a solid blanket covering the surface is most effectively destro, ed. The following aquatic weeds are controlled with socium arsenite and the dosage requjred for each is indicated: 
Pond scum algae (Hydrodictyon, Cedogonium, etc.)

2.5 p.p.m.

Waterweed (Anacharis canadensis, etc.:

2.5 to 4.0 p.p.m.

Hornwort, Coontail (Ceratophyl.lun demersun L.)

2.0 p.p.m.

Parrots feather (Myriophyllum brasiliense Camis.

3.0 to 4.0 p.p.m.

Water milfoil (Wyriophyllum hetercuhyl.um Michx.)

3.0 to 4.0 p.p.m.

Curly-leaf pondweed (P. crispus L.)

2.5 p.p.m.

White water crowfoot (Ranuculus aquatilis L.)

3.0 p.p.m.

Pondweed ( $P$. nodosus Poiret)

$2.5 \mathrm{p} . \mathrm{p} \cdot \mathrm{m}$.

Leafy pondweed ( $P$. foliosus Raf.)

2.0 p.p.m.

Fine-leaf pondweed ( $\mathrm{P}$. filiformis Pers.)

2.0 p.p.m.

Naiad (Najas flexilis (Willd.) R. \& S.)

2.5 p.p.m.

Naiad (Najas guadalupensis (Spreng.) Morong)

$2.5 \mathrm{p} . \mathrm{p} . \mathrm{m}$.

Water stargnass (Heteranthera dubia (Jacq.) MacM.)

2.5 p.p.m.

Water purslane (Ludvigia palustris (L.) Ell.)

3.0 to 4.0 p.p.m.

Bladderwort (Utricuiaria gibba L.)

$2.5 \mathrm{p} . \mathrm{p}=\mathrm{m}_{\mathrm{s}}$

\section{Source of Material}

U.S. Dept. of Interior, Fish \& Wildife Service Fishery Leaflet 344, "Control of Aquatic Plants In Ponds and Lakes".

Chipman Chemical Co., "Use of Sodium Arsenite For Control of Submersed Vegetation in Fish Pords and Lakes".

Tennessee Coriservationist, Sept. 1952,

"Algae Safely Abolished".

Peul M⿻ Stivectecis 

